\title{
Additional sauropod dinosaur material from the Callovian Oxford Clay Formation, Peterborough, UK: evidence for higher sauropod diversity
}

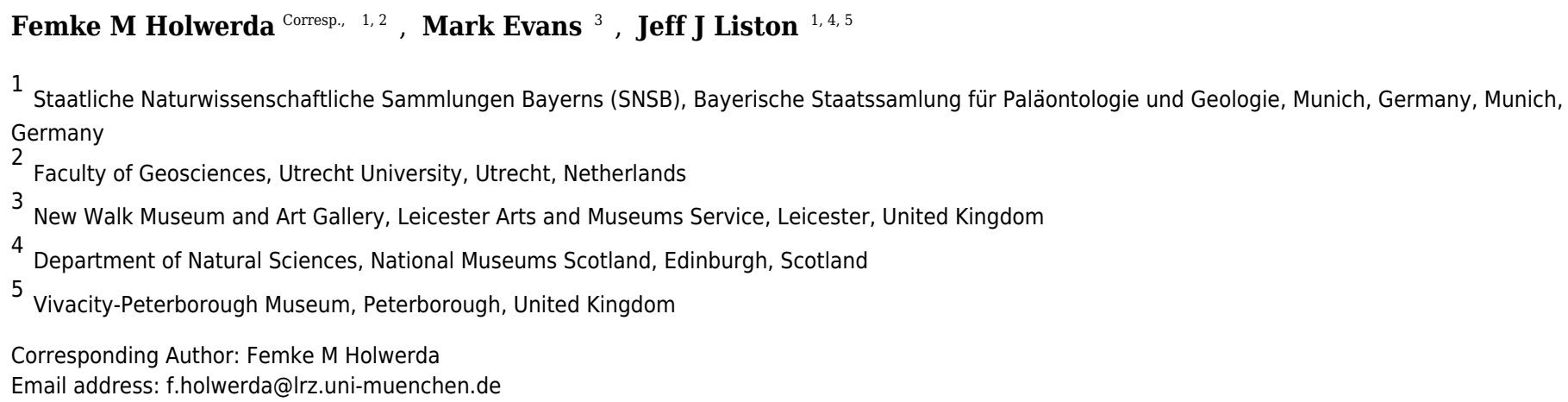

Four isolated sauropod axial elements from the Oxford Clay Formation (Callovian, Middle Jurassic) of Peterborough, UK, are described. Two associated posterior dorsal vertebrae show a dorsoventrally elongated centrum and short neural arch, and nutrient or pneumatic foramina, most likely belonging to a non-neosauropod eusauropod, but showing ambiguous non-neosauropod eusauropod and neosauropod affinities. An isolated anterior caudal vertebra displays a ventral keel, a 'shoulder' indicating a wing-like transverse process, along with a possible prespinal lamina. This, together with an overall high complexity of the anterior caudal transverse process (ACTP) complex, indicates that this caudal could have belonged to a neosauropod. A second isolated middle-posterior caudal vertebra also shows some diagnostic features, despite the neural spine and neural arch not being preserved and the neurocentral sutures being unfused. The positioning of the neurocentral sutures on the anterior one third of the centrum indicates a middle caudal position, and the presence of faint ventrolateral crests, as well as a rhomboid anterior articulation surface, suggest neosauropod affinities. The presence of possible nutrient foramina are only tentative evidence of a neosauropod origin, as they are also found in Late Jurassic non-neosauropod eusauropods. As the caudals from the two other known sauropods from the Peterborough Oxford Clay, Cetiosauriscus stewarti and an indeterminate non-neosauropod eusauropod, do not show the features seen on either of the new elements described, both isolated caudals indicate a higher sauropod species diversity in the faunal assemblage than previously recognised. An exploratory phylogenetic analysis using characters from all four isolated elements supports a basal neosauropod placement for the anterior caudal, and a diplodocid origin for the middle 
caudal. The dorsal vertebrae are an unstable OTU, and therefore remain part of an indeterminate eusauropod of uncertain affinities. Together with Cetiosauriscus, and other material assigned to different sauropod groups, this study indicates the presence of a higher sauropod biodiversity in the Oxford Clay Formation than previously recognised. This study shows that it is still beneficial to examine isolated elements, as these may be indicators for higher species richness in deposits that are otherwise poor in terrestrial fauna. 


\section{Additional sauropod dinosaur material from the Callovian Oxford Clay Formation,}

2 Peterborough, UK: evidence for higher sauropod diversity

3

4 Femke M. Holwerdaa,b*, Mark Evans ${ }^{\mathrm{c}}$, Jeff J. Liston ${ }^{\mathrm{a}, \mathrm{d}, \mathrm{e}}$

5

6 Author affiliations

7

8 a Staatliche Naturwissenschaftliche Sammlungen Bayerns (SNSB), Bayerische Staatssamlung

9 für Paläontologie und Geologie, Munich, Germany

10 b Faculty of Geosciences, Utrecht University, Utrecht, the Netherlands

$11{ }^{\mathrm{c}}$ New Walk Museum and Art Gallery, Leicester Arts and Museums Service, Leicester, United

12 Kingdom

13 d National Museums Scotland, Edinburgh, Scotland

14 e Vivacity-Peterborough Museum, Peterborough, England

*corresponding author: f.holwerda@Irz.uni-muenchen.de

\section{ABSTRACT}

20 Four isolated sauropod axial elements from the Oxford Clay Formation (Callovian, Middle

21 Jurassic) of Peterborough, UK, are described. Two associated posterior dorsal vertebrae show

22 a dorsoventrally elongated centrum and short neural arch, and nutrient or pneumatic foramina,

23 most likely belonging to a non-neosauropod eusauropod, but showing ambiguous non-

24 neosauropod eusauropod and neosauropod affinities. An isolated anterior caudal vertebra

25 displays a ventral keel, a 'shoulder' indicating a wing-like transverse process, along with a

26 possible prespinal lamina. This, together with an overall high complexity of the anterior caudal 
27 transverse process (ACTP) complex, indicates that this caudal could have belonged to a neosauropod. A second isolated middle-posterior caudal vertebra also shows some diagnostic

29 features, despite the neural spine and neural arch not being preserved and the neurocentral

30 sutures being unfused. The positioning of the neurocentral sutures on the anterior one third of

31 the centrum indicates a middle caudal position, and the presence of faint ventrolateral crests, as

32 well as a rhomboid anterior articulation surface, suggest neosauropod affinities. The presence

33 of possible nutrient foramina are only tentative evidence of a neosauropod origin, as they are

34 also found in Late Jurassic non-neosauropod eusauropods. As the caudals from the two other

35 known sauropods from the Peterborough Oxford Clay, Cetiosauriscus stewarti and an

36 indeterminate non-neosauropod eusauropod, do not show the features seen on either of the

37 new elements described, both isolated caudals indicate a higher sauropod species diversity in

38 the faunal assemblage than previously recognised. An exploratory phylogenetic analysis using

39 characters from all four isolated elements supports a basal neosauropod placement for the

40 anterior caudal, and a diplodocid origin for the middle caudal. The dorsal vertebrae are an

41 unstable OTU, and therefore remain part of an indeterminate eusauropod of uncertain affinities.

42 Together with Cetiosauriscus, and other material assigned to different sauropod groups, this

43 study indicates the presence of a higher sauropod biodiversity in the Oxford Clay Formation

44 than previously recognised. This study shows that it is still beneficial to examine isolated

45 elements, as these may be indicators for higher species richness in deposits that are otherwise

46 poor in terrestrial fauna.

\section{INTRODUCTION}

51 Sauropods are represented in the Middle Jurassic of the UK by two named species thus far: the

52 Bajocian-Bathonian Cetiosaurus oxoniensis (Phillips, 1871; Owen, 1875) and the Callovian 
53 Cetiosauriscus stewarti (Charig, 1980, 1993). Cetiosauriscus is known from material found in

54 the Peterborough Oxford Clay, and has thus far not been encountered from other localities

55 (Woodward, 1905; Heathcote \& Upchurch, 2003; Noè, Liston \& Chapman, 2010). The type

56 material comprises a posterior dorsal vertebra, a partial sacrum, a partial caudal axial column,

57 forelimb and partial pectoral girdle, hindlimb, and a partial pelvic girdle (Woodward, 1905). Thus

58 far, it is recovered in phylogenetic analyses as a non-neosauropod eusauropod (e.g. Heathcote

59 \& Upchurch, 2003; Rauhut et al., 2005; Tschopp, Mateus \& Benson, 2015, although in the last

60 analysis, in some trees it is recovered as a basal diplodocoid as well). Another species of

61 Cetiosauriscus, Cetiosauriscus greppini, is known from Switzerland; however, this specimen is

62 from the Late Jurassic, and moreover, has recently been reidentified as a putative basal

63 titanosauriform (Schwarz, Wings \& Meyer, 2007).

64 In addition to Cetiosauriscus, four anterior caudal vertebrae (NHMUK R1984) are known from

65 the Oxford Clay Formation. These were previously ascribed to a brachiosaurid (Upchurch \&

66 Martin, 2003, Noè, Liston \& Chapman, 2010), and have more recently been reidentified as an

67 indeterminate non-neosauropod eusauropod (Mannion et al., 2013. Another sauropod fragment

68 from the Oxford Clay Formation is a partial distal tail segment including ten posterior(most)

69 caudals, which was initially assigned to a diplodocid (Upchurch, 1995; Noè, Liston \& Chapman,

70 2010). However, more recently Whitlock (2011) showed the moderate elongation of these

71 elements to not be conclusive of placement within Diplodocoidea, and furthermore, Mannion et

72 al., (2012) suggested a tentative placement of neosauropod indet, later more cautiously

73 proposed as eusauropod indet (P.Mannion pers. comm. 2018). A partial pelvic girdle, dorsal rib

74 and dorsal centrum NHMUK R1985-1988 (Noè, Liston \& Chapman, 2010), referred to

75 'Ornithopsis leedsi' (Hulke, 1887; Woodward, 1905) from the lower Callovian Kellaways

76 Formation, were recently referred to an indeterminate non-neosauropod eusauropod (Mannion

77 et al., 2013). Finally, three undiagnosed 'camarasaurid' sauropod teeth (Martill, 1988), 
78 tentatively ascribed to Turiasauria (Royo Torres \& Upchurch, 2012) are known from the Oxford

79 Clay. See Table 1 for a list of sauropod material from the Oxford Clay Formation.

80

81 The Middle Jurassic (Callovian) Oxford Clay Formation, UK, has yielded many marine

82 vertebrates (ichthyosaurs, pliosaurids, cryptoclidids and other plesiosaurians, marine

83 crocodylomorphs, sharks, and fishes (Andrews, 1910, 1913)), as well as invertebrates (Leeds,

84 1956). Land-dwelling vertebrates such as dinosaurs, however, are rare from this marine setting.

85 The Jurassic Gallery of the Vivacity-Peterborough Museum in Peterborough, and the New Walk

86 Museum and Art Gallery in Leicester house some of these dinosaur specimens from the Oxford

87 Clay of Peterborough. The material consists of isolated partial elements of a stegosaur, and

88 several isolated sauropod fossils, including a two associated dorsal vertebrae, a partial anterior

89 caudal vertebra and a partial middle caudal vertebra. These elements have been submerged in

90 seawater; however, they do display some characters which may be used for diagnosis.

92 Despite the locality being a classic site for fossils, and many historical finds of marine reptiles

93 having been described and redescribed, the sauropod fauna from the Oxford Clay has not

94 received much attention thus far. Though associated material such as Cetiosauriscus is scarce,

95 isolated material can be studied in detail and reveal information on both morphology and

96 species diversity, which is important for material from the Middle Jurassic of the United

97 Kingdom, as this is relatively scarce (Manning, Egerton \& Romano, 2015). Therefore, we here

98 describe two isolated sauropod dorsal vertebrae, as well as two isolated caudal vertebrae from

99 the collections of the Vivacity-Peterborough Museum and of the New Walk Museum of

100 Leicester, all from the Oxford Clay Formation of Peterborough, United Kingdom (and previously

101 indexed in collections under 'Cetiosaurus'), and compare them to contemporaneous and other 102 sauropod remains. 
103

104 MATERIALS \& METHODS

105

106 Institutional abbreviations

107 PETMG R. = Vivacity-Peterborough Museum, UK

108 LEICT G. = New Walk Museum, Leicester, UK

109 NHMUK = Natural History Museum, London, UK

110 YORYM = York Museums Trust, York, UK

111

112

113 Systematic Palaeontology

114

115 Dinosauria (Owen, 1842)

116

117 Saurischia (Seeley, 1888)

118

119 Sauropoda (Marsh, 1878)

120

121 Eusauropoda (Upchurch, 1995)

122

123 ?Neosauropoda (Bonaparte, 1986a)

124

125

126 Geological and historical setting

127 
128 The two dorsal vertebrae PETMG R85 were found in 1922 by Mr. P.J. Phillips, at London Road,

129 Peterborough, most likely indicating the vertebrae were from the vicinity of either the Woodston

130 or Fletton pits, to the west and east of that roadway (see Figure 1). The ammonite embedded on

131 the specimen is likely a Kosmoceras jasoni, a common ammonite of the Oxford Clay Formation

132 (J.Cope pers. comm. 2018; Hudson \& Martill, 1994).

133 Details on the provenance of the caudal specimen PETMG R272 are sparse, save that it is

134 recorded as being from the King's Dyke pit (see Figure 1). No date of discovery is known.

135 However, the King's Dyke pit first opened in 1969 (Hillier, 1981). Stratigraphically, this pit ranges

136 from the lower Athleta, Phaeinum Subchronozone, down to the Kellaways Sand (Lower

137 Callovian Calloviense Chronozone, K.Paige pers. comm 2018), which is further supported by

138 identifications of bivalves on PETMG R272 as Eonomia timida (T.Palmer pers. comm. 2018).

139 Although LEICT G. 418.1956.21.0 is recorded as being from the Peterborough Oxford Clay

140 Formation, its precise provenance is unknown. The original label on the specimen dates 1956,

141 when a number of brick pits were active, including parts of the Orton, Fletton, Farcet and Yaxley

142 pits (Hillier, 1981, see Figure 1), and in addition there would also be the worked out pits that

143 would be accessible for collectors to search the pit faces and spoil heaps of. The strata of all the

144 Peterborough clay pits extend from the Kellaways Formation up to the Stewartby Member of the

145 Peterborough Formation (see Hudson \& Martill, 1994, for a more detailed geological setting),

146 and therefore date exclusively to the Callovian (Middle Jurassic, 155 Ma).

147

148

149

150

151

152 Morphology 


\section{Dorsal vertebrae PETMG R85}

155 The two associated dorsal vertebrae PETMG R85 (Figure 2 and 3) are incomplete; the first

156 dorsal has the centrum and a small part of the neural arch preserved; the second dorsal only

157 the centrum. Both dorsal elements are partially covered in sediment, probably clay, and are

158 covered with marine invertebrates, showing long-time immersion in seawater. The position of

159 the dorsals is unclear; however, the relative dorsoventral length compared to the anteroposterior

160 length of the centra suggests a more posterior position.

161 The first dorsal shows an oval anterior articular surface, which is dorsoventrally higher than

162 transversely wide, and measures 24,7 by $21,4 \mathrm{~cm}$. The anterior surface (Figure $2 \mathrm{~A}$ ) is slightly

163 convex, whereas the posterior surface (Figure 2B), which is also dorsoventrally longer than

164 transversely wide, is flat to concave, rendering the centrum very slightly opisthocoelous. The

165 posterior articular surface measures 21,3 by $18,3 \mathrm{~cm}$, and shows circular striations on the

166 surface not covered by sediment. The anterior articular surface shows several small bivalves

167 embedded in the matrix covering it, as well as an ammonite (Figure 2A), see Geological setting.

168 It also displays a rim, 'cupping' the articular surface, which is also visible in lateral view (Figure

$1692 \mathrm{E}, \mathrm{F})$. The anterior ventral surface projects further ventrally than the posterior side. In ventral

170 view, the centrum displays rugose anteroposterior striations, as well as a slight constriction of

171 the ventral surface, bordered by two low ridges (Figure 2C). Furthermore, the ventral surface

172 shows several bivalves and small pneumatic foramina. In lateral view, the centrum also shows

173 small pneumatic or nutrient foramina (Figure 2F). Pleurocoels are not visible, only very shallow

174 fossae ventral to the neural arch. The centrum measures $7,6 \mathrm{~cm}$ long anteroposteriorly in right

175 lateral view, and $10,8 \mathrm{~cm}$ in left lateral view, displaying some mild distortion, which is also visible

176 in ventral view (Figure 2C,E,F).

177 The neural arch on the first dorsal in anterior view shows the neural canal to be covered with

178 sediment, making it unclear how large or what shape the neural canal originally was (Figure 
179 2A). The posterior neural canal shows the same sedimentary infill (Figure 2B). As the infill here

180 follows a specific shape, however, it is possible that the neural canal was oval, and

181 dorsoventrally higher than transversely wide, both in anterior and posterior view. Lateroventral

182 to the neural canal, rugosities extend to the base of the diapophyseal laminae; it is unclear what

183 these rugosities are. Dorsolateral to the neural canal, possible prezygapophyseal bases are

184 visible. Ventral to these, the base of the diapophyses is seen, which would project strongly

185 dorsolaterally (Figure 2A). A lip-like structure is seen dorsal to the neural canal, which is also

186 visible in lateral (Figure 2E) and dorsal view (Figure 2D). Dorsal to this structure, both a rugose,

187 triangular prespinal lamina (prsl)/hypanthrum is seen, flanked by two ridges which might be

188 spinoprezygapophyseal laminae (sprl). The posterior neural arch also shows the diapophyseal

189 base to project dorsolaterally (Figure 2B). A similar rugose triangular process is seen dorsal to

190 the posterior neural canal, possibly the postspinal lamina (posl) or a rudimentary hyposphene

191 (Figure 2B). Here too this structure is flanked by two ridges, possibly the

192 spinopostzygapophyseal laminae (spol). Lateral and ventral to this structure, two wide laminae

193 are seen to project dorsolaterally, these could be the centropostzygapophyseal laminae (cpol),

194 which are also visible in lateral (Figure 2E,F) and dorsal (Figure 2D) view. In lateral view, the

195 base of the diapophyses are supported by both an anterior and posterior centrodiapophyseal

196 lamina (acdl, pcdl). In right lateral view, a possible small centrodiapophyseal fossa (cdf) is seen

197 (Figure 2E). Finally, a possible spinodiapophyseal lamina (spdl) is seen to project dorsally to the

198 base of the neural spine (which is not preserved) in both lateral views (Figure 2E,F). The base

199 of the neural spine is seen to project dorsally and slightly posteriorly, making it possible that the

200 neural spine also projected dorsally and posteriorly. In dorsal view, the base of the spine has an

201 oval to rhomboid shape, and is transversely wider than anteroposteriorly long (Figure 2D).

202

203 The second dorsal centrum of PETMG R85 (Figure 3) is preserved without any remnants of the

204 neural arch. The centrum is amphicoelous/amphiplatyan. Neurocentral sutures are tentatively 
205 present on each lateral side of the centrum, however; these are also embedded in sediment.

206 One is slightly visible in dorsal view (Figure 3F). The anterior articular surface (Figure 3A)

207 measures 19,4 cm dorsoventrally and 19,3 cm transversely, and projects slightly further

208 ventrally than the posterior side (Figure 3C,D). It is round in shape, and shows a small ventral

209 indentation, which could be due to taphonomic damage. The surface is covered in matrix, which

210 embeds ammonite and belemnite remains, as well as bivalves, indicating immersion in

211 seawater. The posterior articular surface (Figure 3B) is more oval in shape, and dorsoventrally

212 longer $(17,7 \mathrm{~cm})$ than transversely wide $(13,9 \mathrm{~cm})$. This surface shows rounded striations

213 around the rim, as in the other dorsal. The 'true' surface is partially visible and shows a pitted

214 central surface, whereas a part of the posterior side is also embedded in matrix and bivalves. In

215 right lateral view (Figure 3D), a possible damaged parapophysis is visible ventral to the possible

216 neurocentral suture. The centrum furthermore shows no pleurocoels, only very shallowly

217 concave areas below the possible neurocentral sutures. The surface is covered in shallow, oval

218 nutrient or pneumatic foramina, as in the other dorsal. In ventral view, the centrum is slightly

219 constricted transversely, and is concave, with both articular surfaces fanning out transversely

220 from this constriction. Ventrally, also nutrient or pneumatic foramina are visible. The ventral

221 surface of the centrum shows longitudinal striations.

222

223 Anterior caudal vertebra PETMG R272

224 The anterior caudal PETMG R272 (See Figure 4) measures a maximum of 27,2 cm

225 dorsoventrally and $26,5 \mathrm{~cm}$ transversely. The anterior articular surface measures 23,1 by 24,7 ;

226 the posterior 25,6 by 21,8 . The centrum is $15,3 \mathrm{~cm}$ long anteroposteriorly. It is covered in

227 bivalves which are embedded on the surface of the bone (see Figure 4), demonstrating long-

228 term submersion in seawater and possible epibiont activity (Martill, 1987; Danise, Twitchett \&

229 Matts 2014). The neural spine is missing, as well as the entire left transverse process; the right

230 transverse process is partially preserved at its base. The centrum is transversely wider at its 
231 dorsal side than at the ventral side, and the posterior side protrudes further ventrally than the

232 anterior side. The relative axial compression of the centrum, together with the apparent

233 connection between the neural arch and base of the transverse processes (as far as can be

234 seen) shows this vertebra to be one of the anterior-most caudals.

236 In anterior view (Figure 4A), the articular surface of the centrum is oval to round, and is

237 transversely wider than dorsoventrally high. The outer surface of the articular surface is convex

238 and displays circular striations, as is common for weightbearing bones in sauropods (FH pers

239 obs, $\mathrm{H}$ Mallison pers comm 2018). The internal $\pm 1 / 3 \mathrm{rd}$ of the anterior articular surface is

240 shallowly concave. The entire articular surface is 'cupped' by a thick rim, which mostly follows

241 the oval to round contour of the articular surface, however, it is flattened ventrally, and on the

242 dorsal rim it shows a slight indentation, rendering the dorsal rim heart-shaped. This rim is also

243 seen in lateral view (Figure 4C). In posterior view (Figure 4B), the articular surface is heart-

244 shaped to triangular: the ventral rim ends in a transversely pointed shape, whereas the dorsal

245 rim shows a rounded depression on the midline, flanked by parallel convex bulges. The articular

246 surface itself is concave, with an additional depression in the mid $\pm 1 / 3$ rd part of the surface. The

247 posterior articular surface is less rugosely 'cupped' by its rim than the anterior one.

249 In ventral view (Figure 4D), the posterior rim of the centrum shows rudimentary semilunar

250 shaped chevron facets, which are not seen on the anterior side. The transverse processes are

251 visible as triangular protrusions that project laterally. Below each is a small oval depression. The

252 lateral sides of the centrum are constricted, and flare out towards the anterior and posterior

253 sides. A keel-like structure can be seen on the ventral axial midline of this vertebra. This keel is

254 not visible as a thin protruding line, but more as a broad band protruding slightly ventrally from

255 the ventral part of the centrum. It is possible this keel is formed by the close spacing of the

256 ventrolateral rims of the centrum, as is described for neosauropod anterior caudal vertebrae by 
257 Harris, (2006). In lateral view, the transverse processes are visible as triangular protrusions that

258 project laterally. They are oval in cross-section. Below each is a small, oval, shallow depression.

259 The lateral sides of the centrum are constricted, and flare out towards the anterior and posterior 260 sides.

262 The anterior side of the neural canal and the base of the neural arch are set in a dorsoventrally

263 high, anteroposteriorly flattened sheet of bone, consisting of the

264 spinodiapophyseal/prezygodiapophyseal and centrodiapophyseal laminae, which give the

265 neural arch (without transverse processes and neural spine) a roughly triangular shape (Figure

266 4A). In particular, the high projection on the neural arch of the diapophyseal laminae suggest

267 the existence of a 'shoulder', which would make the transverse processes wing-shaped (see

268 Gallina \& Otero, 2009). However; as the neural arch is incomplete, there is no certainty about

269 the exact shape of the transverse processes and their connection to the neural arch. The neural

270 canal is broadly arched (measuring $3,3 \mathrm{~cm}$ by $3,8 \mathrm{~cm}$ ). Its dorsal rim is overshadowed by a lip-

271 like, triangular protrusion, which could be a remnant of the hypantrum (Figure 4A). Right above

272 this lip-like process, a rugosely striated lamina persists along the dorsoventral midline of the

273 neural arch, up to the dorsal-most rim of the specimen. This may possibly be the scar of a

274 rudimentary single intraprezygapophyseal lamina (stprl, Figure 4A). The posterior side of the

275 neural canal is more teardrop-shaped, and is set within the neural arch, which displays shallow

276 depressions on both sides of the neural canal; these could be small postzygapophyseal

277 spinodiapophyseal fossae (pocdf, sensu Wilson et al., 2011, Figure 4B)). Directly above it, the

278 rami of the bases of the postzygapophyses are clearly visible. The postzygapophyses are

279 rounded to triangular in shape (Figure 4B). A deep oval depression is seen between them; this

280 could be the remnant of the spinopostzygapophyseal fossae (spof, sensu Wilson et al., 2011,

281 Figure 4B). Finally, a V-shaped striated process is seen between the two postzygapophyses,

282 which could be the remnant of the hyposphene. 
284 The transverse processes appear like rounded protuberances, seen in anterior and lateral view

285 (Figure 4A,C). The ventral sides of the bases of both transverse processes are concave. In

286 lateral view, the transverse process has a rounded to triangular shape, and is axially wider

287 ventrally than dorsally. It is dorsally supported by a spinodiapophyseal lamina (spdl, Figure 4E),

288 and seems to have an anterior centrodiapophyseal lamina (acdl); however, a posterior

289 centrodiapophyseal lamina (pcdl) is not clearly visible.

290

291 Middle caudal vertebra LEICT G.418.1956.21.0

292 The middle caudal LEICT G.418.1956.21.0 (Figure 5) is an isolated element, and has no

293 connection with the anterior caudal. Unlike the anterior caudal, this middle caudal centrum is

294 well-preserved, with minute details clearly visible. The neural arch and neural spine are not

295 preserved, and as the unfused neurocentral sutures show, the animal this caudal belonged to,

296 was not fully grown (Brochu, 1996) and probably in Morphological Ontogenetic Stage 2 (MOS

297 2), rather than MOS 1, given the large size (sensu Carballido \& Sander, 2014).

298

299 The centrum is $21,9 \mathrm{~cm}$ long axially, its anterior maximum tranverse width is $21,7 \mathrm{~cm}$ and its

300 posterior maximum width $18,6 \mathrm{~cm}$, with posterior maximum height at $15,2 \mathrm{~cm}$, giving an

301 average Elongation Index (aEl, sensu Chure et al., 2010) of 1,31. The centrum is rectangular in

302 shape, seen in dorsal (Figure 5E) and ventral view (Figure 5F), with mildly flaring anterior and

303 posterior lateral ends of the articulation surfaces. In lateral view (Figure 5B,D), the posterior

304 ventral side protrudes further ventrally than the anterior ventral side. However, the anterior

305 dorsal side projects further dorsally than the posterior side. Transverse processes are only

306 rudimentarily present, as oval, rugose, lateral bulges.

307 
308 The anterior articular surface is rhomboid (hexagonal to almost octagonal) in shape (Figure 5A);

309 the dorsal 1/3rd shows a wide transverse extension of the articular rim, whilst the lower $1 / 3$ rd

310 shows a much narrower width, with sharply beveled constrictions between them. The ventral

311 side shows a rounded indent on the midline, giving this articular surface a heart-shaped ventral

312 rim. The rim itself is about $2-3 \mathrm{~cm}$ thick, shows concentric striations, and protrudes slightly

313 anteriorly. The inner articular surface is flat to concave, however, the kernel shows a rugose

314 rounded protrusion of bone. The morphology of the posterior articular surface (Figure $5 \mathrm{C}$ ) is

315 much more simple, oval in shape, and is wider transversely than dorsoventrally high. The

316 articular rim is less thick than anteriorly; about $1-2 \mathrm{~cm}$. The articular surface is mildly concave,

317 with a dorsal slightly convex bulge, which is common in non-neosauropod eusauropods (e.g.

318 Cetiosaurus, Patagosaurus (FH pers. obs)). The dorsal side of the centrum (Figure 3E) shows

319 well-preserved and unfused neurocentral sutures, which span approximately the anterior 2/3rds

320 of the axial length of the centrum. The ventral half of the neural canal is clearly visible, and

321 shows four axially elongate, deep nutrient foramina embedded within the posterior half of the

322 centrum. A further two shallow nutrient foramina are visible.

323

324 The ventral side of the centrum (Figure 5F) shows two sets of chevron facets, the posterior ones

325 of which are more pronounced. Several rugose striations run along the axial length of the

326 ventral surface, probably for ligament attachments. Along the midline, a ventral hollow (possibly

327 the ventral longitudinal hollow, but this is not clear) runs anteroposteriorly, braced on each

328 lateral side by a rounded, slightly protruding beam. On each lateral side of these, shallow oval

329 asymmetrical depressions are visible; these are caused by preparing away sediment and

330 debris, and could possibly be fossae, but this is uncertain. Two faint ventrolateral crests are also

331 possibly present, also visible in right lateral view (Figure 5B). The crests are not pronounced,

332 and on the left lateral side (Figure 5D) the crest does not run for the entire anteroposterior

333 length. The right lateral side (Figure 5B) furthermore shows a faint longitudinal ridge, however, 
334 in left lateral view (Figure 5D), this ridge does not persist on the entire lateral side of the

335 centrum.

336 The lateral side of the centrum further shows several small nutrient foramina. Faint ridges are

337 visible anterodorsal to the transverse processes, which could be vestigial diapophyseal laminae.

338 Finally, very shallow oval depressions, possibly pneumatic, are seen ventral to the bulges of the

339 transverse processes.

340

341 Phylogenetic framework

342

343 To explore possible phylogenetic relationships, the material studied here is used as separate

344 Operational Taxonomic Units (OTU's). The morphological characters of both dorsals and both

345 caudals of this study were coded in an existing sauropod-based matrix from Carballido et al.,

346 (2017). in Mesquite (Maddison \& Maddison, 2010) using non-neosauropod eusauropods as well

347 as neosauropods. A second analysis used the diplodocoid-based datamatrix from Tschopp \&

348 Mateus, (2017). See supplementary material of Tschopp, Mateus \& Benson, (2015)), for the

349 character matrix, explanatory notes, and references therein. See Supplementary file for this

350 manuscript for both datamatrices including our coding. Only dorsal characters were coded for

351 PETMG R85, anterior caudal characters could be coded for PETMG R272, and only anterior to

352 middle, and middle to posterior characters could be coded for LEICT G.418.1956.21.0. Next to

353 these codings, the anterior and middle caudals of Cetiosauriscus stewarti were recoded, based

354 on the descriptions of Woodward (1905), Charig (1980) and based on pictures of NHMUK

355 R3078 which resulted in some character changes. See Supplemental file for our character

356 matrix, adapted from Tschopp et al., (2015).

357 Both matrices were analysed using TNT (Goloboff, Farris \& Nixon, 2008; Goloboff \& Catalano,

358 2016) using TBR, which yielded 15636 trees. The strict consensus tree shows the dorsals

359 PETMG R85 as grouping with Europasaurus, and both PETMG R272 as well as LEICT 
360 G.418.1956.21.0 to be sister groups, and placed within Macronaria, and sister-group to

361 Diplodocoidea (see Figure 6A). It should be noted, however, that PETMG R85 is unstable in this

362 analysis, and it only takes a few more steps to move these to other nodes in the tree. Moreover,

363 most synapomorphies for the nodes were only applicable to a few caudal characters, which may

364 not be explicit enough for the isolated material of this study.

365 The second analysis using the matrix of Tschopp \& Mateus (2017) using New Technology

366 search recovers four trees where PETMG R272 groups with Cetiosauriscus in Diplodocimorpha,

367 the dorsals PETMG R85 as sister-group to Diplodocidae, and finally LEICT G.418.1956.21.0 as

368 jumping between grouping with Diplodocinae or sister to Rebbachisauridae (see Figure 6B).

369

370

371

372

373

374

375

376

377

378

379

380

381 The first dorsal centrum furthermore shows mild opisthocoely, and both show a slightly more

382 ventral projection of the anterior articular surface. Opisthocoely in posterior dorsals for instance,

383 is seen in Mamenchisaurus, Omeisaurus and Haplocanthosaurus (Hatcher, 1903; He, Li \& Cai,

384 1988; Ouyang \& Ye, 2002) and thus occur both in non-neosauropod eusauropods and in

385 neosauropods. It should be noted, however, that posterior dorsal opisthocoely has not been 
386 found in non-neosauropod eusauropods basal to mamenchisaurids and Omeisaurus, such as

387 Cetiosaurus, Spinophorosaurus, Shunosaurus, Tazoudasaurus, Lapparentosaurus and

388 Patagosaurus (Bonaparte, 1986b,a; Upchurch \& Martin, 2003; Allain \& Aquesbi, 2008; Remes

389 et al., 2009), as wel as in the isolated Oxford Clay Fm dorsal NHMUK R1986, attributed by

390 Mannion (2013) to a non-neosauropod eusauropod (Figure 7G-I). A ventral projection of the

391 anterior articular surface is seen to some extend in Cetiosauriscus (Woodward, 1905) and also

392 in Ferganasaurus (Alifanov \& Averianov, 2003).

393 The ratio of centrum dorsoventral length / neural arch length is roughly 4:1, whereas this is

394 roughly 2:1 in Cetiosauriscus (Woodward, 1905), and also in Haplocanthosaurus, and

395 Apatosaurus (Tschopp, Mateus \& Benson 2015), and roughly 1:1 in Cetiosaurus oxoniensis

396 (Upchurch \& Martin, 2003). It is likely that the neural arch is incomplete, which gives a

397 disproportionately short length. However, the current measurements offset these dorsals from

398 being related to Cetiosauriscus.

399 Pronounced dorsal projection of the diapophyses in dorsal vertebrae is a character shared with

400 Shunosaurus, Cetiosaurus, turiasaurians, Haplocanthosaurus, and dicraeosaurids (Hatcher,

401 1903; Zhang, 1988; Casanovas, Santafé \& Sanz, 2001; Upchurch \& Martin, 2003; Rauhut et al.,

402 2005) and are thus also present in a wide array of both non-neosauropod and neosauropod

403 dinosaurs (See Figure 7A-C).

404 Small nutrient or pneumatic foramina on the centrum is seen in the dicraeosaurid Suuwassea;

405 however, in this taxon, the foramina express on the anterior caudals (Harris, 2006). Moreover,

406 the lack of any clear pleurocoels on the centra of PETMG R85 might rule out any neosauropod

407 connection. The only dorsal vertebra of Cetiosauriscus shows a small but pronounced

408 pleurocoel (Woodward, 1905).

409 To summarize, more characters indicative of a non-neosauropod eusauropod origin are present

410 in PETMG R85. Some neosauropod characters exist; however, some of these are also shared

411 with non-neosauropod eusauropods. 
412

\section{Anterior caudal vertebra PETMG R272}

415 The anterior caudal PETMG R272 shows characteristics shared with both non-neosauropod

416 eusauropods, as well as neosauropods.

417 The slightly more rounded shape of the centrum in lateral view is shared with Apatosaurus.

418 Anterior caudals of Cetiosauriscus are strongly axially compressed, as also seen in non-

419 neosauropod eusauropods such as Cetiosaurus and Patagosaurus (Woodward, 1905; Charig,

420 1980; Bonaparte, 1986b; Upchurch \& Martin, 2003).

421 The flat anterior articular surface and the mildly concave posterior articular surface of the

422 centrum is a common feature, shared with non-neosauropod eusauropods (e.g. Cetiosaurus,

423 Patagosaurus (Bonaparte, 1986b; Upchurch \& Martin, 2003). The thick rim cupping the anterior

424 surface is found in early Middle Jurassic non-neosauropod eusauropods (Cetiosaurus) but also

425 in the (non-neosauropod eusauropod/potentially basal neosauropod) Callovian Cetiosauriscus

426 (Woodward, 1905; Charig, 1980; Heathcote \& Upchurch, 2003) and in the Oxfordian basal

427 titanosauriform Vouivria damparisensis (Mannion, Allain \& Moine, 2017). The morphology of the

428 ventrally offset anterior articular surface, together with pronounced chevron facets, is seen in

429 non-neosauropod eusauropods from the Late Jurassic of Portugal (Mocho et al., 2017);

430 however, this type of asymmetry is also seen in Apatosaurus louisae (Harris 2006).

431

432 A ventral keel is found in an Early Jurassic indeterminate sauropod caudal from York, UK

433 (YORYM:2001.9337; Manning, Egerton \& Romano, 2015), as well as the Middle Jurassic

434 indeterminate non-neosauropod eusauropod 'Bothriospondylus' NHMUK R2599 (Mannion,

435 2010), and finally, in material ascribed to the non-neosauropod eusauropod Patagosaurus

436 (MACN-CH 232, FH pers obs). However, this structure is also found in neosauropods,

437 specifically in flagellicaudatans and diplodocids Apatosaurus ajax, Apatosaurus louisae, and the 
438 dicraeosaurid Suuwassea (Harris, 2006; Tschopp, Mateus \& Benson, 2015). These have a

439 ventral keel which results from a transverse constriction of the ventral side of the centrum,

440 forming a triangular protrusion on the ventral articular surface. This is also seen in non-

441 neosauropod cervicals (such as Cetiosaurus, Patagosaurus, Spinophorosaurus, Amygdalodon,

442 Tazoudasaurus; Bonaparte, 1986b; Rauhut, 2003; Upchurch \& Martin, 2003; Allain \& Aquesbi,

443 2008; Remes et al., 2009). The latter keel-like form, which seems to match more with the

444 morphology of PETMG R272, forms when there is a very close association of the two

445 ventrolateral ridges that run along the ventralmost side of the centrum, and is only seen in

446 neosauropods (Harris, 2006; Tschopp, Mateus \& Benson, 2015). No keel-like structure is seen

447 in anterior caudals of Cetiosauriscus, nor on the Callovian NHMUK R1984 caudals from the

448 Oxford Clay (Upchurch \& Martin, 2003, Noè, Liston \& Chapman, 2010); the ventral surface of

449 these anterior caudal vertebrae appearing to be smooth.

450

451 The triangular shape of the anterior caudal transverse process (ACTP) complex (Gallina \&

452 Otero, 2009) in PETMG R272 is seen to a lesser extent in non-neosauropod eusauropods, such

453 as Tazoudasaurus, Omeisaurus, and Shunosaurus, but also in an unnamed anterior caudal

454 from a possible titanosauriform, but as yet indeterminate eusauropod from the Bajocian of

455 Normandie, France, and in indeterminate non-neosauropod sauropods from the Late Jurassic of

456 Portugal (He, Li \& Cai, 1988; Zhang, 1988; Allain \& Aquesbi, 2008; Läng, 2008; Mocho et al.,

457 2017). The pronounced shape, however, is more suggestive of 'wing'-shaped transverse

458 processes, due to the possible existence of a 'shoulder' (see Figure 2). This is used as a caudal

459 character to define diplodocids (Whitlock, 2011; Tschopp, Mateus \& Benson, 2015), and is

460 found neither in non-neosauropod eusauropods nor the Bajocian French caudal. However, it is

461 also seen in other neosauropods, such as Camarasaurus and titanosauriforms (Gallina \& Otero,

462 2009). To a lesser extent, a triangular, sheet-like ACTP is seen in Cetiosauriscus (See Figure

463 8), as well as the NHMUK R1984 caudals from the Oxford Clay, however, the anterior caudals 
464 of Cetiosauriscus do not show a pronounced 'shoulder'. Moreover, the transverse processes of

465 PETMG R272 are robust, and rounded to triangular in cross-section, whereas those of

466 Cetiosauriscus are gracile, dorsoventrally elongated and axially compressed, providing a more

467 oval cross-section. Though suggestive of a triangular ACTP, the lack of any clear transverse

468 processes on PETMG R272 rule out any firm conclusion on their morphology.

469 The presence of clearly defined centrodiapophyseal laminae is considered to be a local

470 autapomorphy in the Late Jurassic titanosauriform Vouivria (Mannion, Allain \& Moine, 2017).

471 PETMG R272 does show short rugose centrodiapophyseal laminae.

472

473 To summarize, more characters indicative of a neosauropod origin of this caudal are present

474 than those indicative of a non-neosauropod (eu)sauropod origin. However, due to the lack of

475 complete transverse processes and neural spine, several morphological characters remain

476 ambiguous.

477

478

Middle caudal vertebra LEICT G.418.1956.21.0

480

481 The middle caudal LEICT G.418.1956.21.0 also shows characters shared with non-

482 neosauropod eusauropods, as well as neosauropods.

483 The rhomboid, hexagonal to octagonal shape of the anterior articular surface is not seen in

484 Cetiosauriscus; the middle caudal articular surfaces of the latter are rather round to oval in

485 shape. Hexagonal articular surfaces are a derived condition found in neosauropods, such as

486 Apatosaurus ajax, Suuwassea, but also in Camarasaurus, Demandasaurus and Dicraeosaurus

487 (Upchurch \& Martin, 2002; Tschopp, Mateus \& Benson, 2015). Octagonal articular surfaces are

488 also a derived feature seen in Dicraeosaurus and the potential neosauropod Cetiosaurus

489 glymptoniensis (Upchurch \& Martin, 2003; Harris, 2006). 
490 The anterior placement of the neural spine is another neosauropod character seen in

491 diplodocids and in titanosauriforms (Tschopp, Mateus \& Benson 2015).

492 The ventrolateral crests seen on the ventral side of this caudal are a neosauropod feature,

493 found in many Late Jurassic neosauropods (Harris, 2006; Mocho et al., 2017). See Figure 9 for

494 lateral comparisons. The ventral hollow seen in LEICT G.418.1956.21.0 is also found in several

495 neosauropods, such as Tornieria, Diplodocus, Supersaurus, but also Demandasaurus and

496 Isisaurus (Tschopp et al., 2017). However, it is also seen in an unnamed caudal vertebra from

497 the Bajocian-Bathonian of Skye, UK (Liston, 2004). The ventral hollow is also present in

498 Cetiosauriscus (Figure 9), though not as pronounced as in LEICT G.418.1956.21.0.

499 The longitudinal ridge is another neosauropod feature, though it is also present in non-

500 neosauropod eusauropods, e.g. Omeisaurus (Ouyang \& $\mathrm{He}, 2002$ ). A longitudinal ridge is seen

501 on both Cetiosauriscus and LEICT G.418.1956.21.0 (See Figure 9), as are the lateral pneumatic

502 foramina on the centra, and the ventrolateral crests.

503 Nutrient foramina are seen on the Late Jurassic dicraeosaurid Suuwassea (Harris, 2006), but

504 also on Late Jurassic Portuguese non-neosauropod eusauropods; small foramina on the ventral

505 surface of the centrum are also seen in the anterior caudals of non-neosauropod eusauropods

506 from Late Jurassic of Portugal (Mocho et al., 2017).

507 In summary, more neosauropod characters than non-neosauropod eusauropod characters exist

508 on this caudal centrum; however, as the element is incomplete, the exact placement of this

509 caudal remains uncertain.

510

511 Phylogenetic signal and implications for biodiversity

512

513 The phylogenetic analysis shows the isolated elements of this study to be unstable OTU's; in

514 the first analysis based on Carballido et al., (2017), the dorsal elements jump between a

515 position of non-neosauropod to a position nested in Macronaria, with the caudal elements 
516 nested a few steps below Camarasaurus. In the second analysis based on Tschopp, Benson \&

517 Mateus, (2015), the middle caudal element jumps between being sister-taxon to

518 Rebbachisauridae and being nested in Diplodocidae. This, together with the low number of

519 steps needed to break any relationships, shows that the characters on the isolated elements

520 remain ambiguous, as a plesiomorphic array of characters are present. Any implications for

521 sauropod biodiversity in the Peterborough Oxford Clay Formation must therefore be regarded

522 with some caution.

523 Nevertheless, the possibility exists that in addition to Cetiosauriscus, a neosauropod

524 assemblage (consisting of either diplodocimorph and diplodocid, or rebbachisaurid and

525 diplodocimorph, or macronarian) was present in the Callovian Oxford Clay Formation.

526 No formal Callovian neosauropod is known thus far, with only derived non-neosauropod

527 eusauropods (e.g. Omeisaurus, Jobaria, Ferganasaurus, Atlasaurus, He, Li \& Cai, 1988; Zhang,

528 1988; Monbaron, Russell \& Taquet, 1999; Alifanov \& Averianov, 2003; Rauhut \& López-

529 Arbarello, 2009) diagnosed. Confirmed neosauropods start to appear in the fossil record in later

530 stages, e.g., from the Oxfordian of France, Vouivria has recently been identified as the earliest

531 titanosauriform (Mannion, Allain \& Moine, 2017). The Kimmeridgian-Tithonian fossil record

532 shows neosauropods to be firmly established globally in the fossil record (Mannion et al., 2011,

533 and referinces therein), with a peak occurrence in diplodocids, macronarians and

534 titanosauriforms from especially the North American Morrison, the Portuguese Lourinhã, and the

535 Tanzanian Tendaguru Formations (including a basal macronarian form from the Kimmeridgian

536 of Germany (Foster, 2003; Remes, 2007, 2009; Mannion et al., 2012, 2013; Carballido \&

537 Sander, 2014; Mocho, Royo-Torres \& Ortega, 2014; Tschopp, Mateus \& Benson, 2015). The

538 earliest rebbachisaurid has recently been identified from the UK as well; the Early Cretaceous

539 Xenoposeidon (Taylor 2018), after which rebbachisaurs have been relatively common in Europe

540 and Gondwana (Mannion, 2009; Mannion, Upchurch \& Hutt, 2011; Holwerda et al., 2018). 
541 Moreover, early Middle Jurassic neosauropods are possibly present in the Toarcian-Bajocian of

542 Argentina (Rauhut 2003; Holwerda, Pol \& Rauhut 2015) and Aalenian of China (Xu et al., 2018).

543 Therefore, the presence of Callovian neosauropods present in the UK would not be wholly

544 unsurprising. Though evidently not as species-rich as the later Kimmeridgian-Tithonian

545 Tendaguru, Morrison or Lourinhã Formation, the Peterborough Oxford Clay material thus far

546 has thus hinted at an equivalent degree of higher level taxonomic diversity to those three classic

547 terrestrial Late Jurassic formations; however, as the material from this study is incomplete, the

548 diagnosis of indeterminate non-neosauropod eusauropod or at best indeterminate neosauropod,

549 is appropriate. Finally, Cetiosauriscus will be revised in the near future (P.Upchurch pers.

550 comm. 2018), therefore further studies on more material may clarify the origin of these remains.

551

552

553

554

555

556

CONCLUSIONS

557

558 In summary, the associated posterior dorsals show characters shared with both non-

559 neosauropod eusauropods, as well as neosauropods. These elements will therefore be ascribed

560 to an indeterminate non-neosauropod eusauropod. The anterior isolated caudal shares a few

561 morphological features with non-neosauropod eusauropods, and most morphological features

562 with neosauropods. The middle isolated caudal shares a few features with non-neosauropod

563 eusauropods, and more with neosauropods. It is therefore possible that these caudals belong to

564 a neosauropod dinosaur, which are also different to Cetiosauriscus. Phylogenetic analysis

565 tentatively recovers these caudals as neosauropodan. Therefore, these vertebrae give a higher

566 sauropod diversity to the Peterborough Oxford Clay Formation than previously assumed. 


\section{ACKNOWLEDGEMENTS}

569

570 The authors would like to thank Glenys Wass and the staff of Vivacity-Peterborough Museum

571 for kindly providing access to the specimen, as well as to the late Arthur Cruickshank of the New

572 Walk Museum, Leicester, for preparing the Leicester material. Furthermore, All McGowan, Tim

573 Palmer, John Cope and Kevin Page are thanked for providing invaluable information on the

574 Oxford Clay invertebrate fossils. Darren Withers helped in identifying the provenance of the

575 Peterborough clay pits. Emanuel Tschopp is thanked for discussion on his dataset. The

576 suggestions and comments by editor Matt Wedel, reviewers Phil Mannion, Darren Naish and

577 one anonymous reviewer greatly improved this paper. We acknowledge the Willi Hennig Society

578 for phylogenetic analysis using TNT.

579

580

581

582 Figure captions

583

584 Figure 1: Geological setting - geographical setting of King's Dyke, Orton and Star Pit,

585 Whittlesey (adapted after Hudson \& Martill (1994) with notes from Liston (2006)).

586

587 Figure 2: Posterior dorsal PETMG R85 in anterior (A), posterior (B), ventral (C), dorsal (D), right 588 lateral $(E)$ and left lateral $(F)$ views. Scalebar is $10 \mathrm{~cm}$.

590 Figure 3: Posterior dorsal PETMG R85 in anterior (A0, posterior (B), left lateral (C), right lateral

591 (D), ventral (E) and dorsal (F) views. Scalebar is $10 \mathrm{~cm}$. 
593 Figure 4: Anterior caudal PETMG PETMG R272 in anterior (A), posterior (B), lateral (C), ventral

594 (D), and dorsal (E) views. Scalebar is $10 \mathrm{~cm}$.

595

596 Figure 5: Middle caudal Leict LEICT G.418.1956.21.0 in anterior (A) right lateral (B), posterior

597 (C), left lateral (D), dorsal (E), ventral $(F)$ views. Scalebar $10 \mathrm{~cm}$.

598

599 Figure 6: Phylogenetic analyses. Strict consensus tree based on Carballido et al., (2017) (A)

600 and second analysis based on Tschopp \& Mateus (2017) (B) with revised Cetiosauriscus

601 (purple) coding, and additionally PETMG R85 (orange) PETMG R272 (blue) and LEICT

602 G.418.1956.21.0 (red) as OTU's.

603

604 Figure 7: Comparative schematic drawings of PETMG R85 with posterior dorsals of other 605 sauropods. The Rutland Cetiosaurus (A), Cetiosauus oxoniensis (B)and PETMG R 85 (C) in 606 anterior view, and PETMG R85 (D) with Cetiosauriscus (E) and NHMUK R1986 (F) in posterior 607 view. PETMG R85 in lateral view (G) with Cetiosauriscus $(\mathrm{H})$ and NHMUK R1986 (I). PETMG 608 R85 in ventral view (J) with NHMUK R1986 (K). Scalebar is $10 \mathrm{~cm}$, Cetiosauriscus not to scale. 609

610 Figure 8: Comparative schematic drawings of PETMG R272 with anterior caudals of other 611 sauropods. PETMG R 272 in anterior view (A) with Cetiosaurus oxoniensis (B), Cetiosauriscus

612 (C) and an indeterminate non-neosauropod eusauropod from the Middle Jurassic of the UK 613 (YORYM:2001.9337; Manning, Egerton \& Romano, 2015), (D). PETMG R272 in posterior view 614 (E) compared to NHMUK R1984 (F) in posterior view (after Noé, Liston \& Chapman 2010).

615 Scalebar $10 \mathrm{~cm}$, Cetiosauriscus and NHMUK R1984 not to scale.

616

617 Figure 9: Comparative schematic drawings of LEICT G. 418.1956.21.0 with middle caudals of 618 other sauropods. LEICT G. 418.1956.21.0 in lateral view (A) with the Rutland Cetiosaurus (B), 
619 Cetiosauriscus (C) and Cetiosaurus oxoniensis (D). Scalebar $10 \mathrm{~cm}$, Cetiosauriscus not to 620 scale.

621

622 References

623

624 Alifanov VR., Averianov AO. 2003. Ferganasaurus verzilini, gen. et sp. nov., a new neosauropod (Dinosauria, Saurischia, Sauropoda) from the Middle Jurassic of Fergana Valley, Kirghizia. Journal of Vertebrate Paleontology 23:358-372.

Allain R., Aquesbi N. 2008. Anatomy and phylogenetic relationships of Tazoudasaurus naimi (Dinosauria, Sauropoda) from the late Early Jurassic of Morocco. Geodiversitas 30:345-

Andrews CW. 1910. A Descriptive Catalogue of the Marine Reptiles of the Oxford Clay: Based on the Leeds Collection in the British Museum (Natural History), London Part I. British Museum (Natural History), London, England.

Andrews CW. 1913. A Descriptive Catalogue of the Marine Reptiles of the Oxford Clay: Based on the Leeds Collection in the British Museum (Natural History), London, Part 2. order of the Trustees. British Museum (Natural History), London, England. sauropod dinosaurs, based on vertebral anatomy. In: Padian K ed. The Beginning of the (Vert.-Invert.) 72:247-289. 
642 Brochu CA. 1996. Closure of neurocentral sutures during crocodilian ontogeny: Implications for 643 maturity assessment in fossil archosaurs. Journal of Vertebrate Paleontology 16:49-62. DOI: 10.1080/02724634.1996.10011283.

645 Carballido JL., Pol D., Otero A., Cerda IA., Salgado L., Garrido AC., Ramezani J., Cúneo NR., 646 Krause JM. 2017. A new giant titanosaur sheds light on body mass evolution among sauropod dinosaurs. Proceedings of the Royal Society B 284:20171219. DOI: 10.1098/rspb.2017.1219.

Carballido JL., Sander PM. 2014. Postcranial axial skeleton of Europasaurus holgeri (Dinosauria, Sauropoda) from the Upper Jurassic of Germany: implications for sauropod ontogeny and phylogenetic relationships of basal Macronaria. Journal of Systematic Palaeontology 12:335-387. DOI: 10.1080/14772019.2013.764935.

Casanovas ML., Santafé JV., Sanz JL. 2001. Losillasaurus giganteus , un nuevo saurópodo del tránsito Jurásico-Cretácico de la cuenca de" Los Serranos"(Valencia, España). Paleontologia i Evolució:99-122.

Charig AJ. 1980. A diplodocid sauropod from the Lower Cretaceous of England. In: Jacobs LL ed. Aspects of Vertebrate History. Essays in Honor of Edwin Harris Colbert. Flagstaff: Museum of Northern Arizona Press, 231-244.

Charig AJ. 1993. Case 1876. Cetiosauriscus von Huene, 1927 (Reptilia, Sauropodomorpha): proposed designation of C. stewarti Charig, 1980 as the type species. Bulletin of Zoological Nomenclature 50:282-283. 
662 Chure D., Britt B., Whitlock J., Wilson J. 2010. First complete sauropod dinosaur skull from the 663 Cretaceous of the Americas and the evolution of sauropod dentition. Naturwissenschaften 97:379-391. DOI: 10.1007/s00114-010-0650-6.

665 Danise S., Twitchett RJ., Matts K. 2014. Ecological succession of a Jurassic shallowwater ichthyosaur fall. Nature Communications, 5:4789 doi: $10.1038 /$ ncomms5789

667

Foster JR. 2003. Paleoecological analysis of the vertebrate fauna of the Morrison Formation

669 (Upper Jurassic), Rocky Mountain Region, U.S.A. New Mexico Museum of Natural History and Science Bulletin 23:2-100.

Gallina PA., Otero A. 2009. Anterior caudal transverse processes in sauropod dinosaurs: morphological, phylogenetic and functional aspects. Ameghiniana 46:165-176.

673 Goloboff PA., Catalano SA. 2016. TNT version 1.5, including a full implementation of phylogenetic morphometrics. Cladistics 32:221-238.

675 Goloboff PA., Farris JS., Nixon KC. 2008. TNT, a free program for phylogenetic analysis. Cladistics 676 24:774-786. DOI: 10.1111/j.1096-0031.2008.00217.x.

677 Harris JD. 2006. The axial skeleton of the dinosaur Suuwassea emilieae (Sauropoda: Flagellicaudata) from the Upper Jurassic Morrison Formation of Montana, USA. Palaeontology 49:1091-1121.

Hatcher JB. 1903. Osteology of Haplocanthosaurus, with description of a new species and 681 remarks on the probable habits of the Sauropoda and the age and origin of the Atlantosaurus beds: Additional remarks on Diplodocus. Memoirs of the Carnegie Museum 2:1-72. 
684 He X., Li K., Cai K. 1988. The Middle Jurassic dinosaur fauna from Dashanpu, Zigong, Sichuan.

685

686

687

688

689

690

691

692

693

694

695

696

697

698

699

700

701

702

703

704

705

Vol. IV. Sauropod Dinosaurs (2) Omeisaurus tianfuensis. Chengdu, China: Sichuan Publishing House of Science and Technology.

Heathcote J., Upchurch P. 2003. The relationships of Cetiosauriscus stewarti (Dinosauria; Sauropoda): implications for sauropod phylogeny. Journal of Vertebrate Paleontology 23:60A.

Hillier R. 1981. Clay that burns: a history of the Fletton brick industry. London Brick Company.

Holwerda FM, Díaz VD, Blanco A, Montie R, Reumer JWF. 2018. Late Cretaceous sauropod tooth morphotypes may provide supporting evidence for faunal connections between North Africa and Southern Europe. PeerJ 6:e5925. DOI: 10.7717/peerj.5925.

Hulke JW. 1887. Note on some dinosaurian remains in the collection of A. Leeds, Esq., of Eyebury, Northamptonshire. Quarterly Journal of the Geological Society 43:695-702.

Läng É. 2008. Les cétiosaures (Dinosauria, Sauropoda) et les sauropodes du Jurassique moyen: révision systématique, nouvelles découvertes et implications phylogénétiques. Ph. D. dissertation Thesis. Paris, France: Centre de recherche sur la paléobiodiversité et les paléoenvironnements.

Leeds ET. 1956. The Leeds Collection of Fossil Reptiles from the Oxford Clay of Peterborough. BH Blackwell.

Liston JJ. 2004. A re-examination of a Middle Jurassic sauropod limb bone from the Bathonian of the Isle of Skye. Scottish Journal of Geology 40:119-122.

Maddison WP., Maddison DR. 2010. Mesquite: a modular system for evolutionary analysis. 2011; Version 2.75. See mesquiteproject.org/mesquite/download/download. html. 
706 Manning PL., Egerton VM., Romano M. 2015. A New Sauropod Dinosaur from the Middle 707 Jurassic of the United Kingdom. PLOS ONE 10:e0128107. DOI: 10.1371/journal.pone.0128107.

Mannion PD. 2009. A rebbachisaurid sauropod from the Lower Cretaceous of the Isle of Wight, England. Cretaceous Research 30:521-526.

711 Mannion PD. 2010. A revision of the sauropod dinosaur genus 'Bothriospondylus' with a redescription of the type material of the Middle Jurassic form 'B. madagascariensis.' Palaeontology 53:277-296. DOI: 10.1111/j.1475-4983.2009.00919.x.

714 Mannion PD., Allain R., Moine O. 2017. The earliest known titanosauriform sauropod dinosaur and the evolution of Brachiosauridae. PeerJ 5:e3217.

Mannion PD., Upchurch P., Barnes RN., Mateus O. 2013. Osteology of the Late Jurassic Portuguese sauropod dinosaur Lusotitan atalaiensis (Macronaria) and the evolutionary history of basal titanosauriforms. Zoological Journal of the Linnean Society 168:98-206. DOI: 10.1111/zoj.12029.

Mannion PD., Upchurch P., Hutt S. 2011. New rebbachisaurid (Dinosauria: Sauropoda) material from the Wessex Formation (Barremian, Early Cretaceous), Isle of Wight, United Kingdom. Cretaceous Research 32:774-780.

723

Mannion PD, Upchurch P, Carrano MT, Barrett PM. 2011. Testing the effect of the rock record on diversity: a multidisciplinary approach to elucidating the generic richness of sauropodomorph dinosaurs through time. Biological Reviews 86:157-181. anatomy and systematic position of Dinheirosaurus lourinhanensis (Sauropoda: 

10.1080/14772019.2011.595432.

732

733

734 735 Science (series 3) 16:411-416. DOI: 10.2475/ajs.s3-16.95.411.

Martill DM. 1987. A taphonomic and diagenetic case study of a partially articulated ichthyosaur. Palaeontology 30(3):543-555.

Martill DM. 1988. A review of the terrestrial vertebrate fossils of the Oxford Clay (CallovianOxfordian) of England. Mercian Geologist 11:171.

Mocho P., Royo-Torres R., Malafaia E., Escaso F., Ortega F. 2017. First occurrences of nonneosauropod eusauropod procoelous caudal vertebrae in the Portuguese Upper Jurassic record. Geobios 50:23-36.

Mocho P., Royo-Torres R., Ortega F. 2014. Phylogenetic reassessment of Lourinhasaurus alenquerensis, a basal Macronaria (Sauropoda) from the Upper Jurassic of Portugal. Zoological Journal of the Linnean Society 170:875-916. DOI: 10.1111/zoj.12113.

Monbaron M, Russell DA, Taquet P. 1999. Atlasaurus imelakei ng, n. sp., a brachiosaurid-like sauropod from the Middle Jurassic of Morocco alen. Comptes Rendus de l'Académie des Sciences-Series IIA-Earth and Planetary Science 329:519-526.

Noè LF., Liston JJ., Chapman SD. 2010. 'Old bones, dry subject': the dinosaurs and pterosaur collected by Alfred Nicholson Leeds of Peterborough, England. Geological Society, London, Special Publications 343:49-77. 
750 Ouyang H., Ye Y. 2002. The first mamenchisaurian skeleton with complete skull,

751 Mamenchisaurus youngi. Chengdu, China: Sichuan Publishing House of Science and

752 Technology.

753 Owen R. 1842. Report on British Fossil Reptiles Pt. II. Report of the British Association for the $754 \quad$ Advancement of Science 1841:60-204.

755 Owen R. 1875. Monographs on the British fossil Reptilia of the Mesozoic Formations, Part II

756 (Genera Bothriospondylus, Cetiosaurus, Omosaurus). Palaeontographical Society

757 (Monograph):1-93.

758 Phillips J. 1871. Geology of Oxford and the Valley of the Thames. Clarendon Press.

759 Rauhut OWM. 2003. Revision of Amygdalodon patagonicus Cabrera, 1947 (Dinosauria,

760 Sauropoda). Fossil Record 6:173-181.

761 Rauhut OW, López-Arbarello A. 2009. Considerations on the age of the Tiouaren Formation

762 (Iullemmeden Basin, Niger, Africa): implications for Gondwanan Mesozoic terrestrial

763 vertebrate faunas. Palaeogeography, Palaeoclimatology, Palaeoecology 271:259-267.

764 Remes K. 2007. A second Gondwanan diplodocid dinosaur from the Upper Jurassic Tendaguru 765 beds of Tanzania, East Africa. Palaeontology 50:653-667.

766

Remes K. 2009. Taxonomy of Late Jurassic diplodocid sauropods from Tendaguru (Tanzania). Fossil Record 12:23-46.

Remes K., Ortega F., Fierro I., Joger U., Kosma R., Ferrer JMM., Ide OA., Maga A. 2009. A new basal sauropod dinosaur from the Middle Jurassic of Niger and the early evolution of Sauropoda. PLoS One 4:e6924. DOI: 10.1371/journal.pone.0006924. 
771 Schwarz D., Meyer CA., Wings O., Le Loeuff J. 2007. Revision of Cetiosauriscus greppini-new

772

773

774

775

776

777

778

779

780

781

782

783

784

785

786

787

788

789

790

791 results and perspectives. In: Fifth Meeting of the European Association of Vertebrate Palaeontologists Abstract Volume, Musée des Dinosaures, Espéraza, France. 57-58.

Schwarz D., Wings O., Meyer C. 2007. Revision of Cetiosauriscus greppini: the revival of a Late Jurassic sauropod from Switzerland. In: Journal of Vertebrate Paleontology 143A-143A.

Seeley HG. 1888. Classification of the Dinosauria. Geological Magazine (Decade III) 5:45-46.

Taylor MP. 2018. Xenoposeidon is the earliest known rebbachisaurid sauropod dinosaur. PeerJ 6:e5212.

Tschopp E., Mateus O. 2017. Osteology of Galeamopus pabsti sp. nov. (Sauropoda: Diplodocidae), with implications for neurocentral closure timing, and the cervico-dorsal transition in diplodocids. PeerJ 5:e3179. DOI: 10.7717/peerj.3179.

Tschopp E., Mateus O., Benson RBJ. 2015. A specimen-level phylogenetic analysis and taxonomic revision of Diplodocidae (Dinosauria, Sauropoda). PeerJ 3:e857. DOI: 10.7717/peerj.857.

Upchurch P. 1995. The evolutionary history of sauropod dinosaurs. Philosophical Transactions of the Royal Society of London. Series B: Biological Sciences 349:365-390.

Upchurch P., Mannion PD., Taylor MP. 2015. The Anatomy and Phylogenetic Relationships of "Pelorosaurus" becklesii (Neosauropoda, Macronaria) from the Early Cretaceous of England. PLoS One 10:e0125819.

Upchurch P., Martin J. 2002. The Rutland Cetiosaurus: the anatomy and relationships of a Middle Jurassic British sauropod dinosaur. Palaeontology 45:1049-1074. 
792 Upchurch P., Martin J. 2003. The anatomy and taxonomy of Cetiosaurus (Saurischia, Sauropoda) 793 from the Middle Jurassic of England. Journal of Vertebrate Paleontology 23:208-231.

794 Whitlock JA. 2011. A phylogenetic analysis of Diplodocoidea (Saurischia: Sauropoda). Zoological Journal of the Linnean Society 161:872-915. DOI: 10.1111/j.1096-3642.2010.00665.x.

796 797

810

811
Wilson JA. 1999. A nomenclature for vertebral laminae in sauropods and other saurischian dinosaurs. Journal of Vertebrate Paleontology 19:639-653.

Wilson JA., D’Emic MD., Ikejiri T., Moacdieh EM., Whitlock JA. 2011. A nomenclature for vertebral fossae in sauropods and other saurischian dinosaurs. PLOS ONE 6:e17114.

Woodward AS. 1905. On parts of the skeleton of Cetiosaurus leedsi, a sauropodous dinosaur from the Oxford Clay of Peterborough. Proceedings of the Zoological Society of London 1:232-243.

Xu X., Upchurch P., Mannion PD., Barrett PM., Regalado-Fernandez OR., Mo J., Ma J., Liu H. 2018. A new Middle Jurassic diplodocoid suggests an earlier dispersal and diversification of sauropod dinosaurs. Nature communications 9:2700.

Zhang Y. 1988. The Middle Jurassic dinosaur fauna from Dashanpu, Zigong, Sichuan, vol. 1: sauropod dinosaur (I): Shunosaurus. Chengdu, China: Sichuan Publishing House of Science and Technology, 114pp. 
Figure 1 (on next page)

Geographical position of King's Dyke, Orton and Star Pit, Whittlesey, UK.

(adapted after Hudson \& Martill (1994), with notes from Liston, (2006)). 


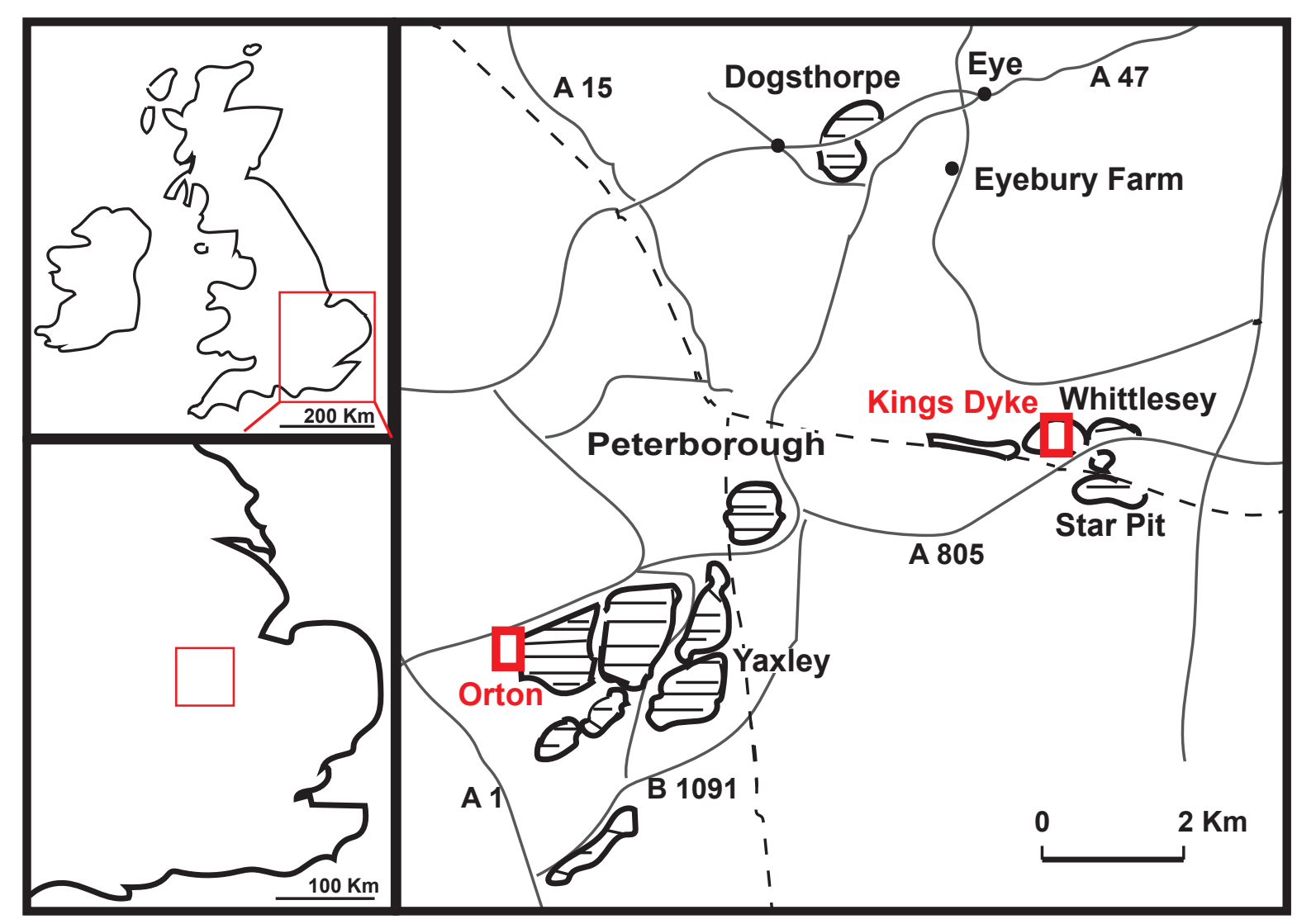


Figure 2

Figure 2: Posterior dorsal PETMG R85.

In anterior $(A)$, posterior $(B)$, ventral $(C)$, dorsal $(D)$, right lateral $(E)$ and left lateral $(F)$ views.

Scalebar is $10 \mathrm{~cm}$.
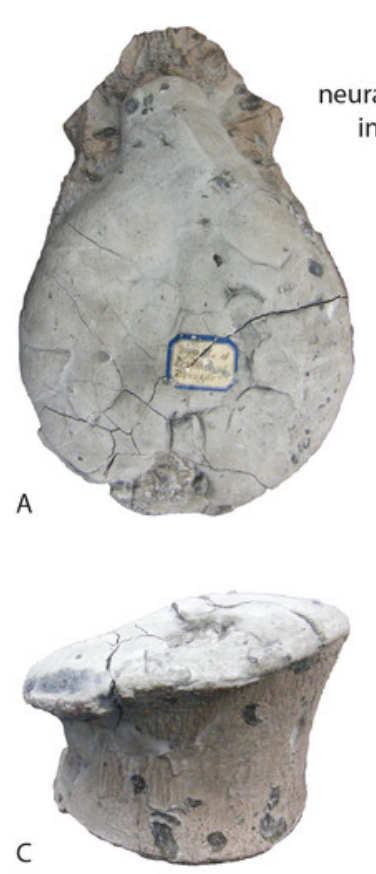

$\mathrm{E}$

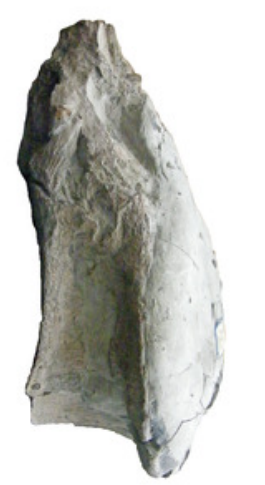

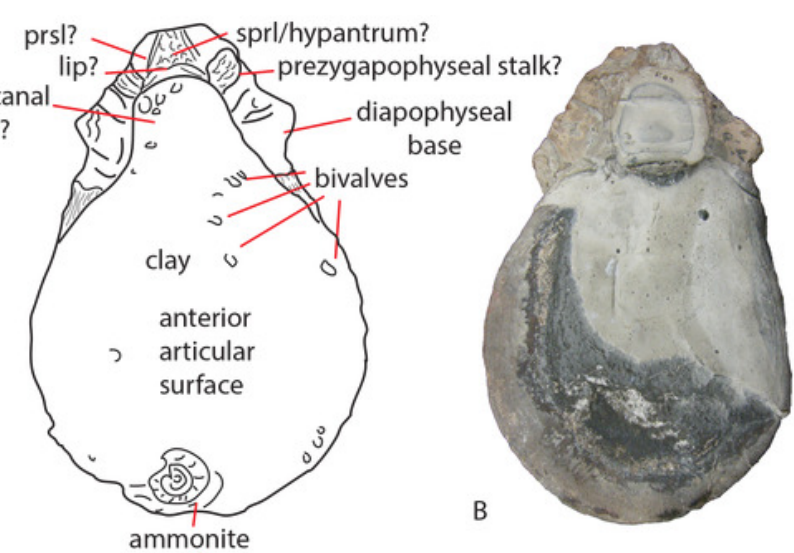
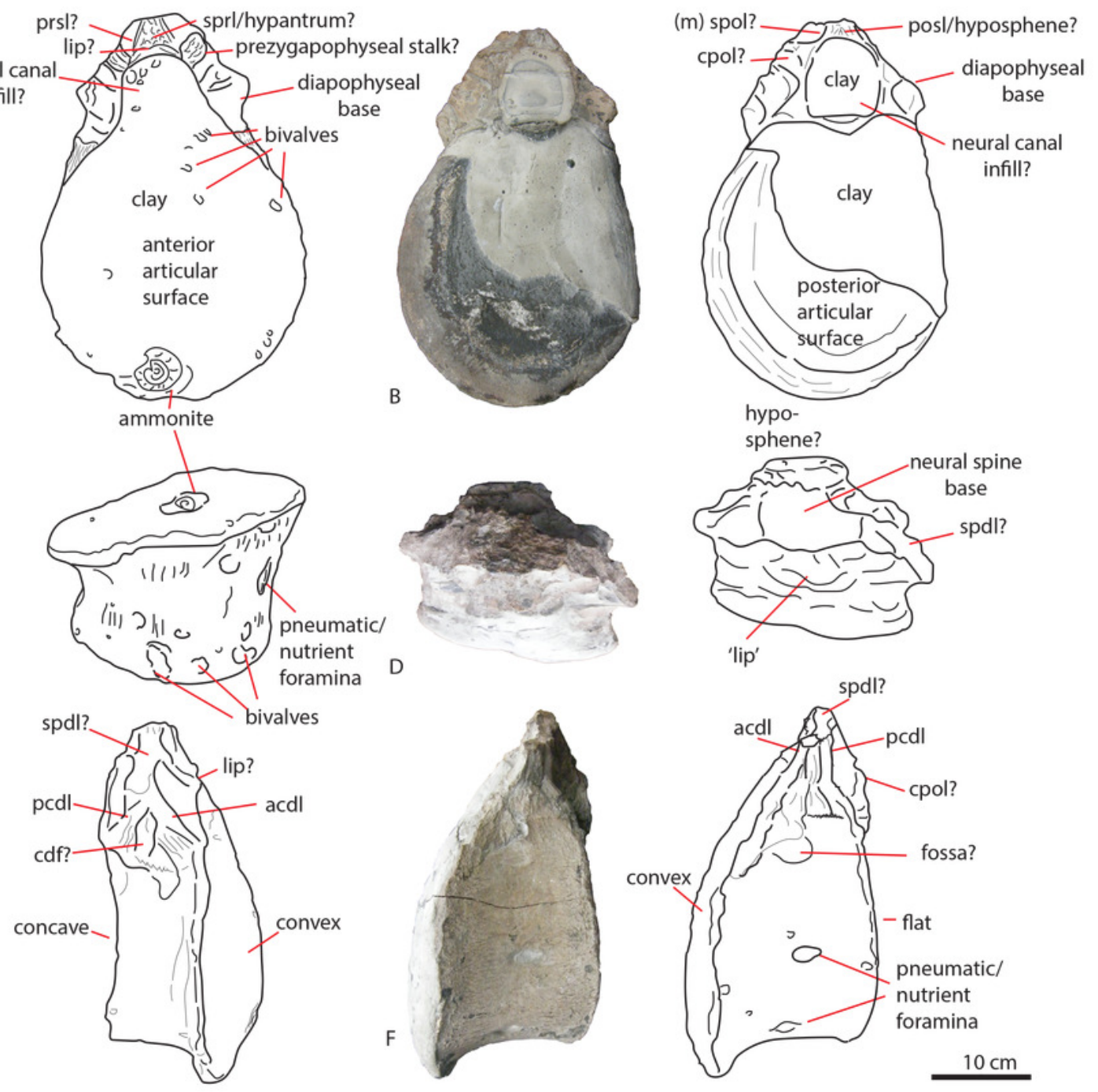
Figure 3

Figure 3: Posterior dorsal PETMG R85.

In anterior ( $A 0$, posterior $(B)$, left lateral $(C)$, right lateral $(D)$, ventral $(E)$ and dorsal $(F)$ views.

Scalebar is $10 \mathrm{~cm}$.
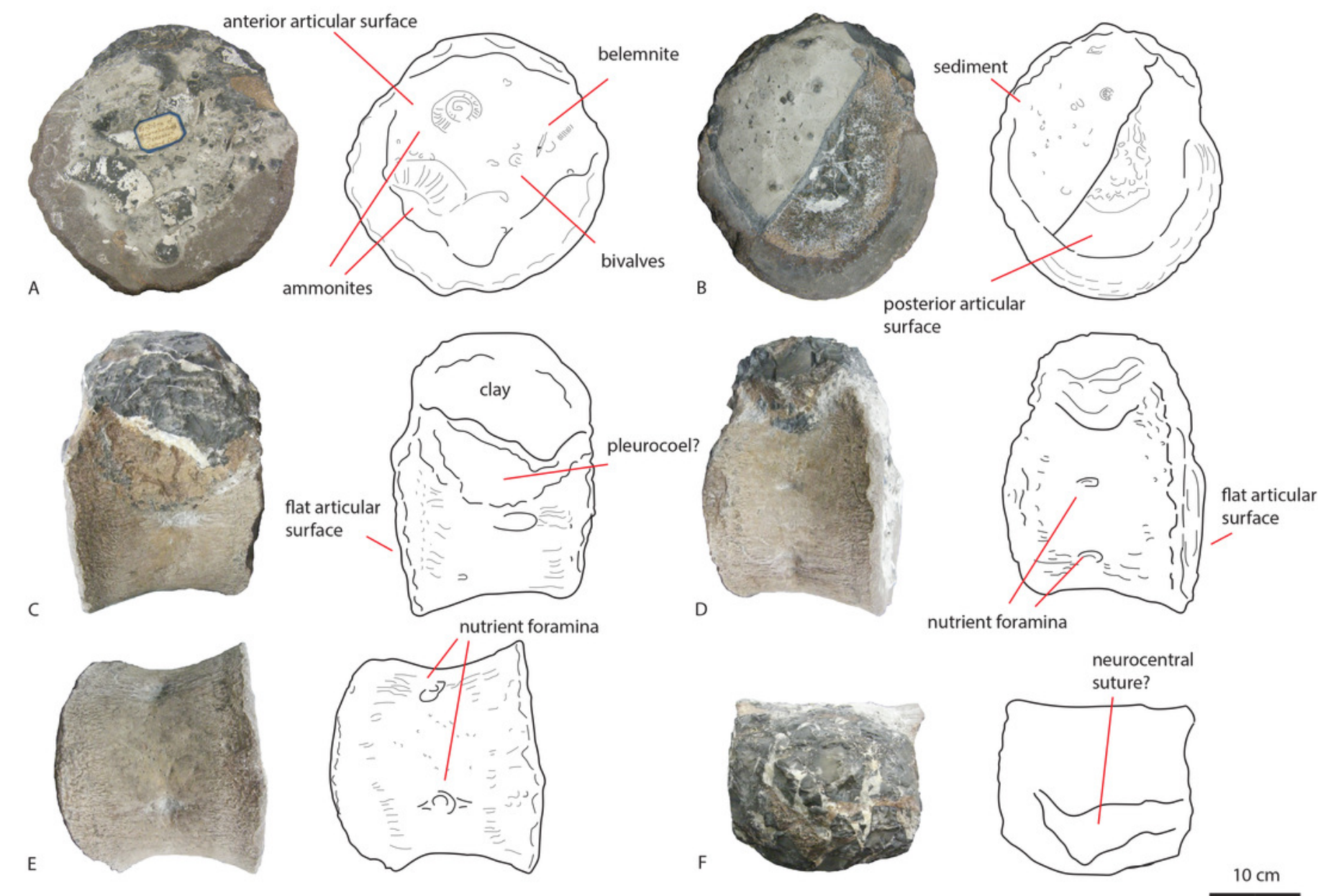


\section{Figure 4}

Figure 4: Anterior caudal PETMG R272.

In anterior (A), posterior (B), lateral (C), ventral (D), and dorsal (E) views. Scalebar is $10 \mathrm{~cm}$.
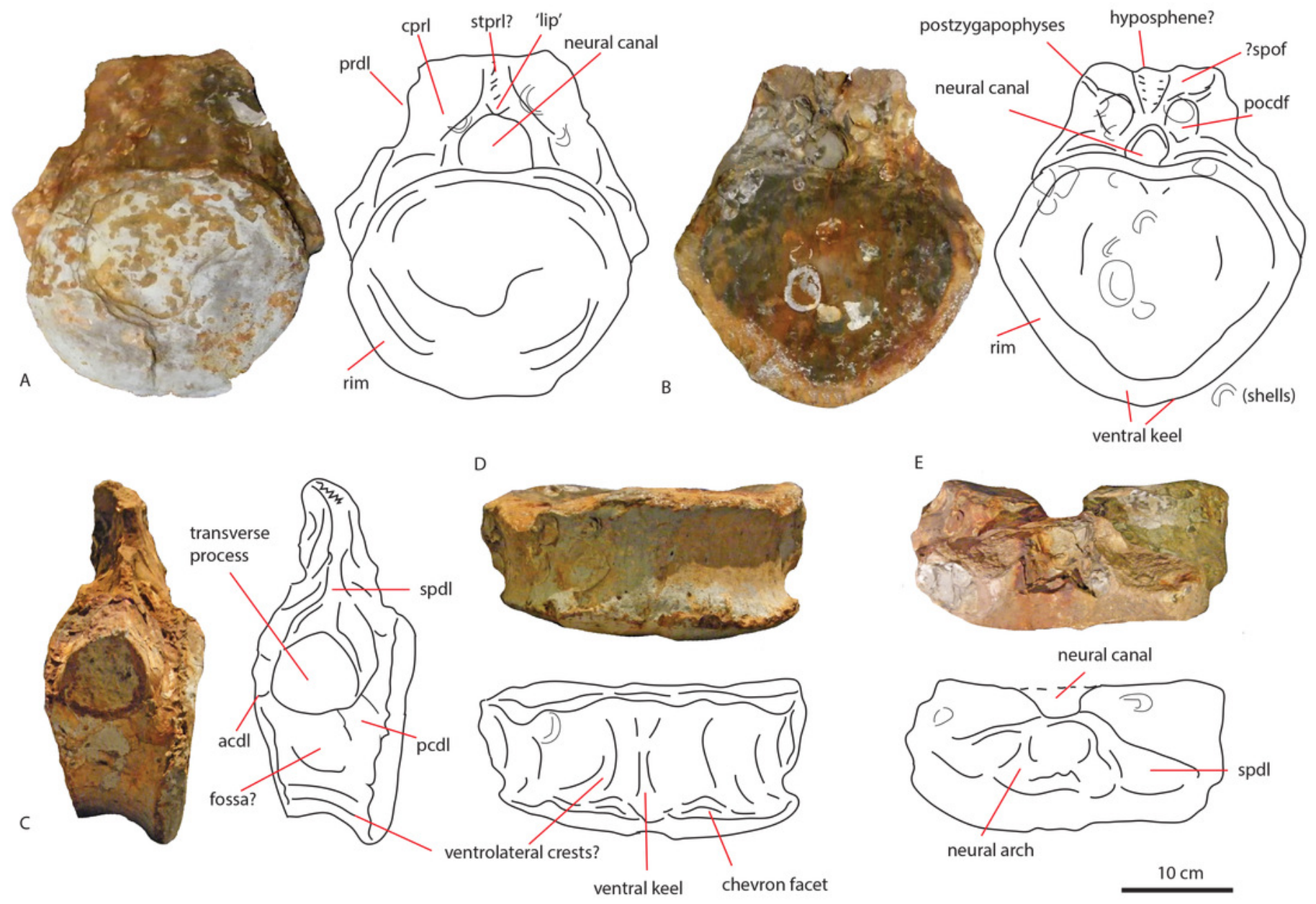

$\mathrm{E}$
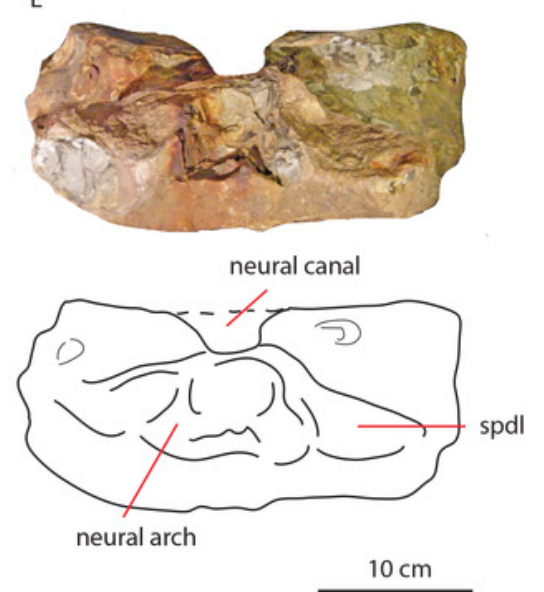
Figure 5

Figure 5: Middle caudal Leict LEICT G.418.1956.21.0.

In anterior $(A)$ right lateral $(B)$, posterior $(C)$, left lateral $(D)$, dorsal $(E)$, ventral $(F)$ views.

Scalebar $10 \mathrm{~cm}$.
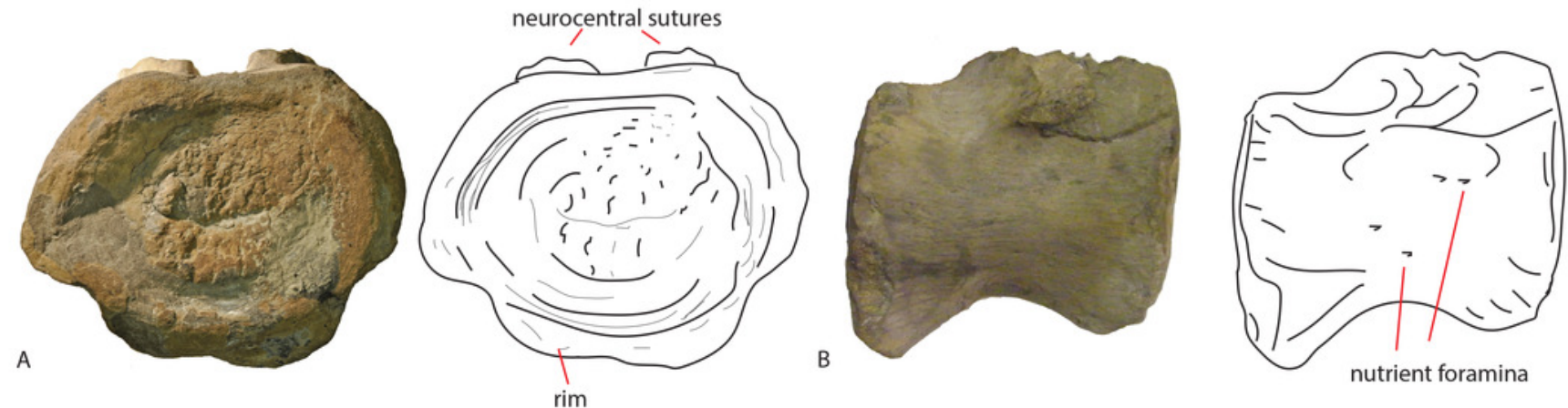

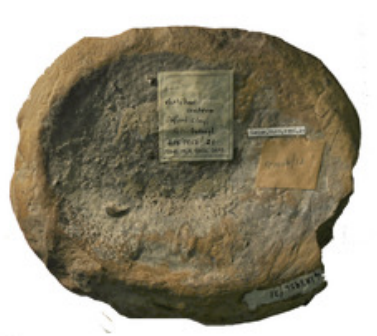

C
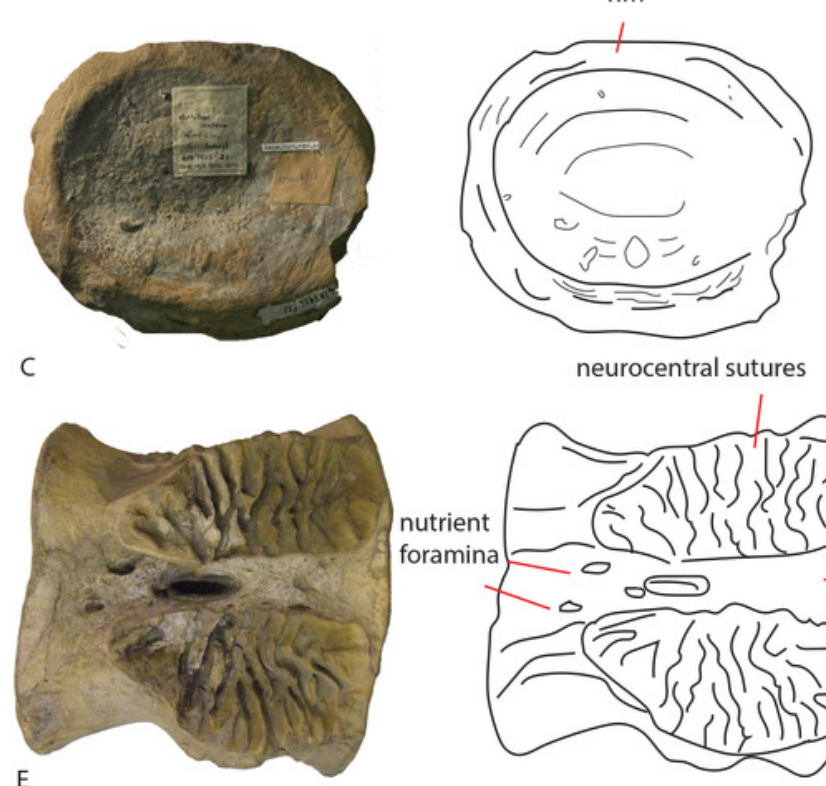

neurocentral sutures

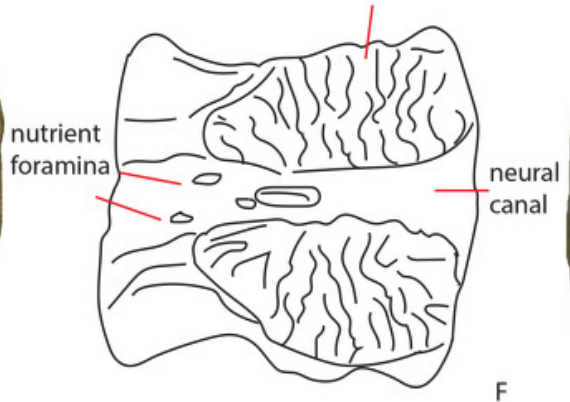

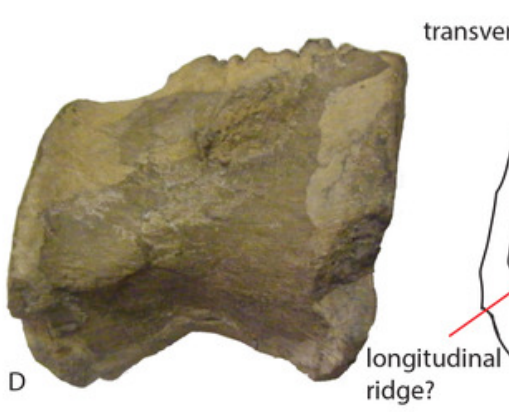

transverse process

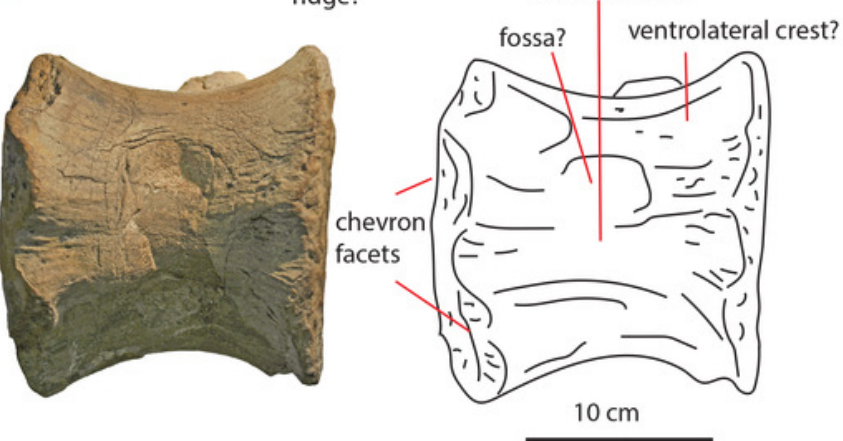




\section{Figure 6 (on next page)}

Figure 6: Phylogenetic analyses.

Strict consensus tree based on Carballido et al., (2017) (A) and second analysis based on Tschopp \& Mateus (2017) (B) with revised Cetiosauriscus (purple) coding, and additionally PETMG R85 (orange) PETMG R272 (blue) and LEICT G.418.1956.21.0 (red) as OTU's. 


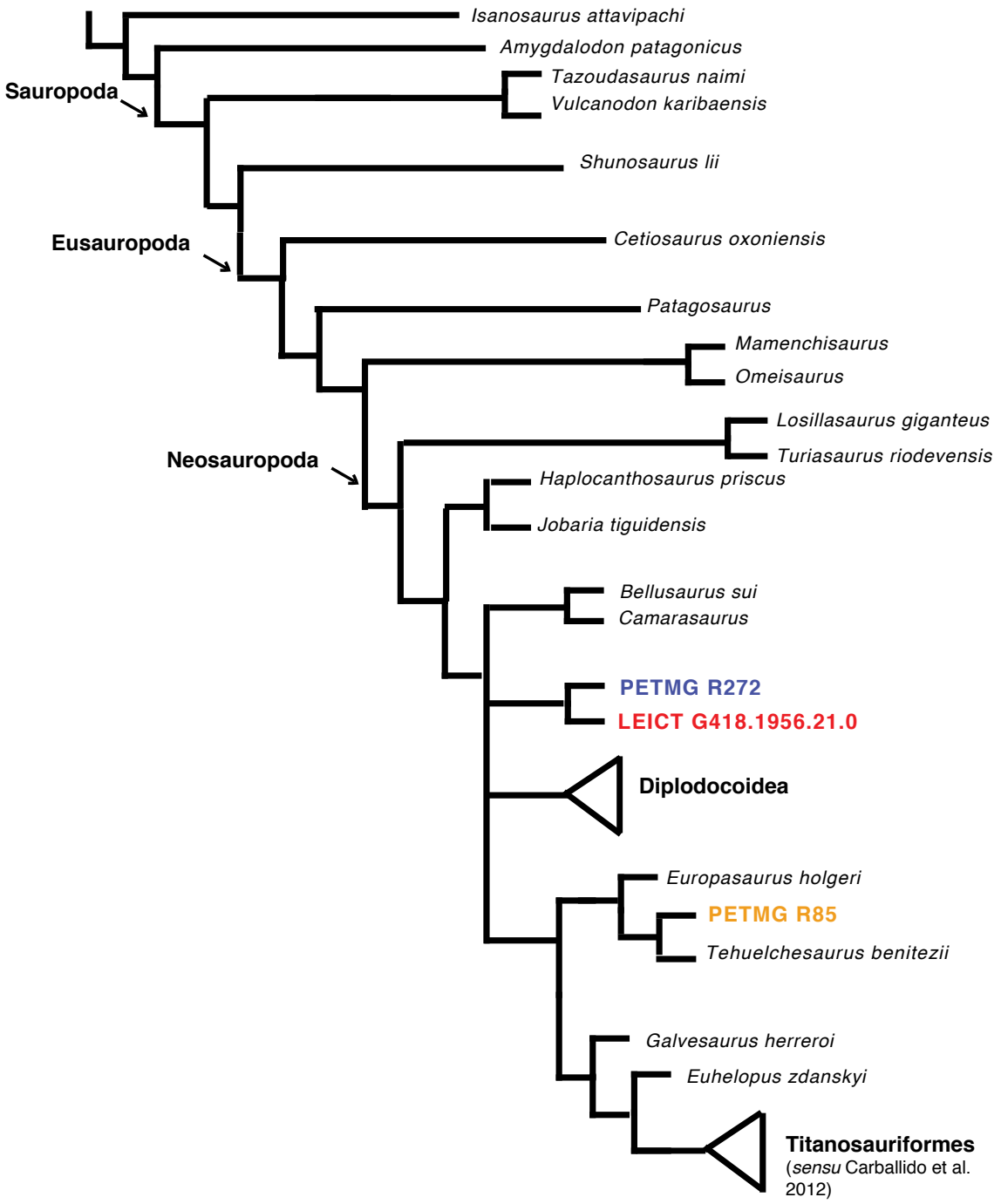

(basal Manuscript to be reviewed

B auropodomorpha)

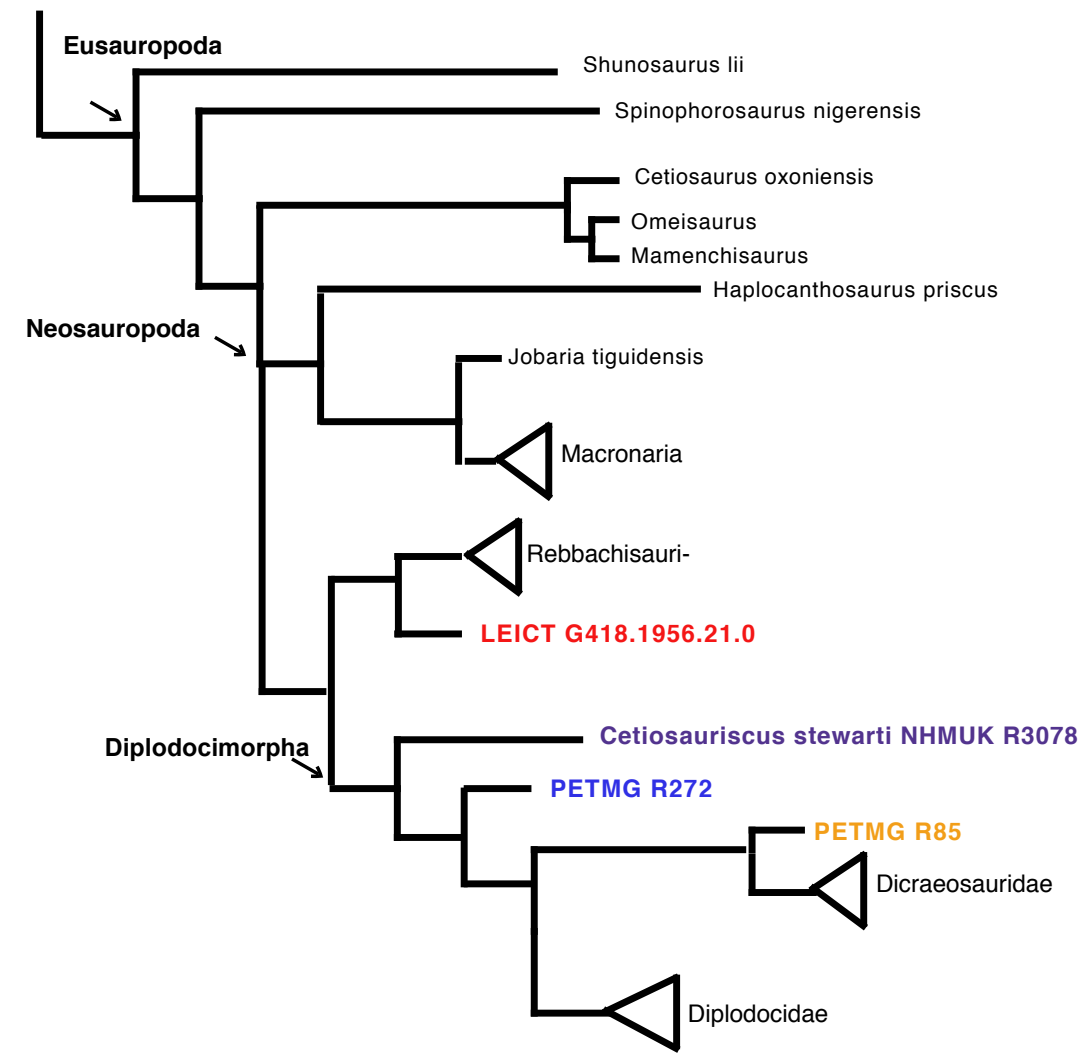


Figure 7 (on next page)

Figure 7: Comparative schematic drawings of PETMG R85 with posterior dorsals of other sauropods.

The Rutland Cetiosaurus (A), Cetiosauus oxoniensis (B)and PETMG R 85 (C) in anterior view, and PETMG R85 (D) with Cetiosauriscus (E) and NHMUK R1986 (F) in posterior view. PETMG R85 in lateral view (G) with Cetiosauriscus (H) and NHMUK R1986 (I). PETMG R85 in ventral view (J) with NHMUK R1986 (K). Scalebar is $10 \mathrm{~cm}$, Cetiosauriscus not to scale. 


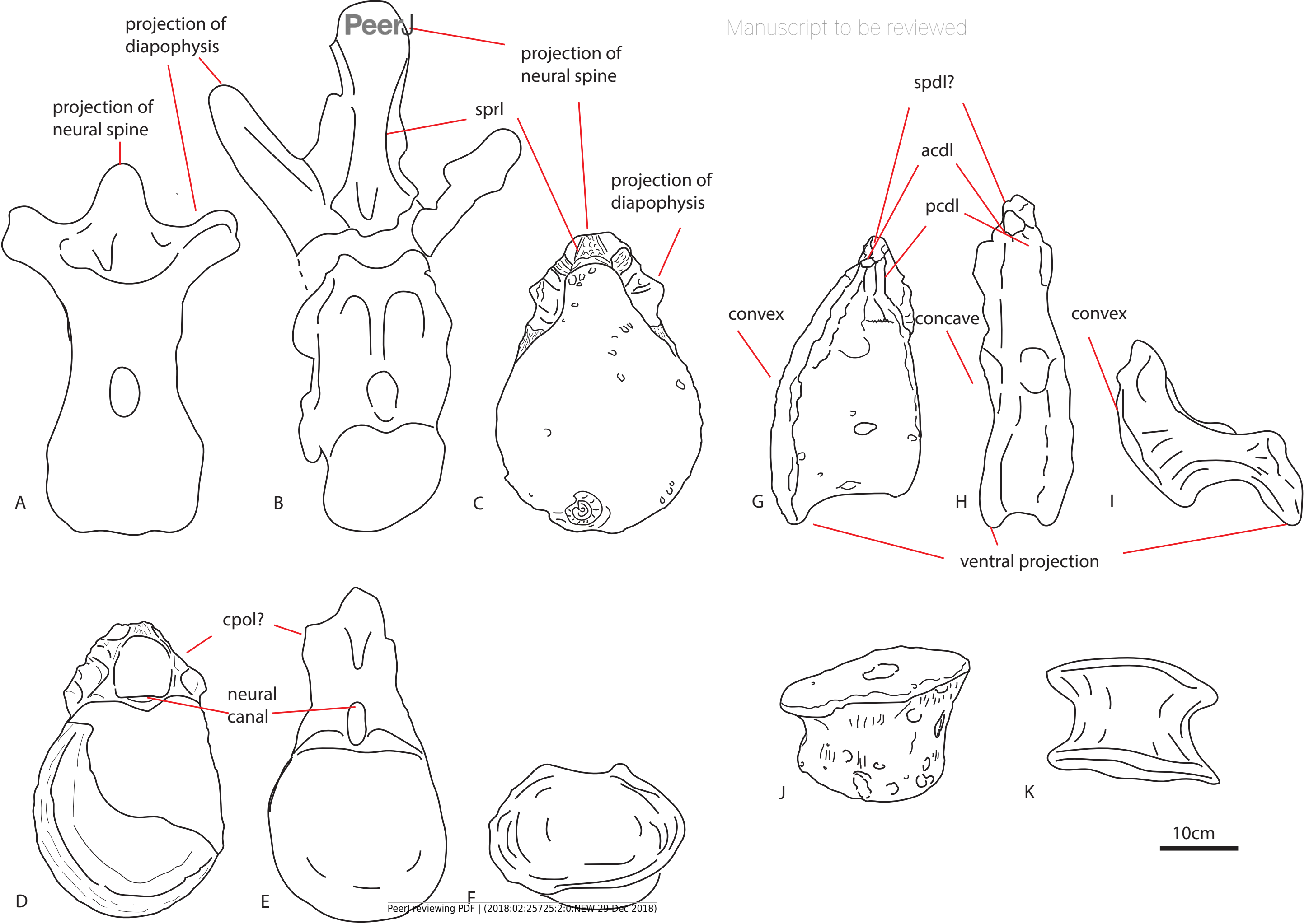




\section{Figure 8 (on next page)}

Figure 8: Comparative schematic drawings of PETMG R272 with anterior caudals of other sauropods.

PETMG R 272 in anterior view (A) with Cetiosaurus oxoniensis (B), Cetiosauriscus (C) and an indeterminate non-neosauropod eusauropod from the Middle Jurassic of the UK (YORYM:2001.9337; Manning, Egerton \& Romano, 2015), (D). PETMG R272 in posterior view (E) compared to NHMUK R1984 (F) in posterior view (after Noé, Liston \& Chapman 2010). Scalebar $10 \mathrm{~cm}$, Cetiosauriscus and NHMUK R1984 not to scale. 


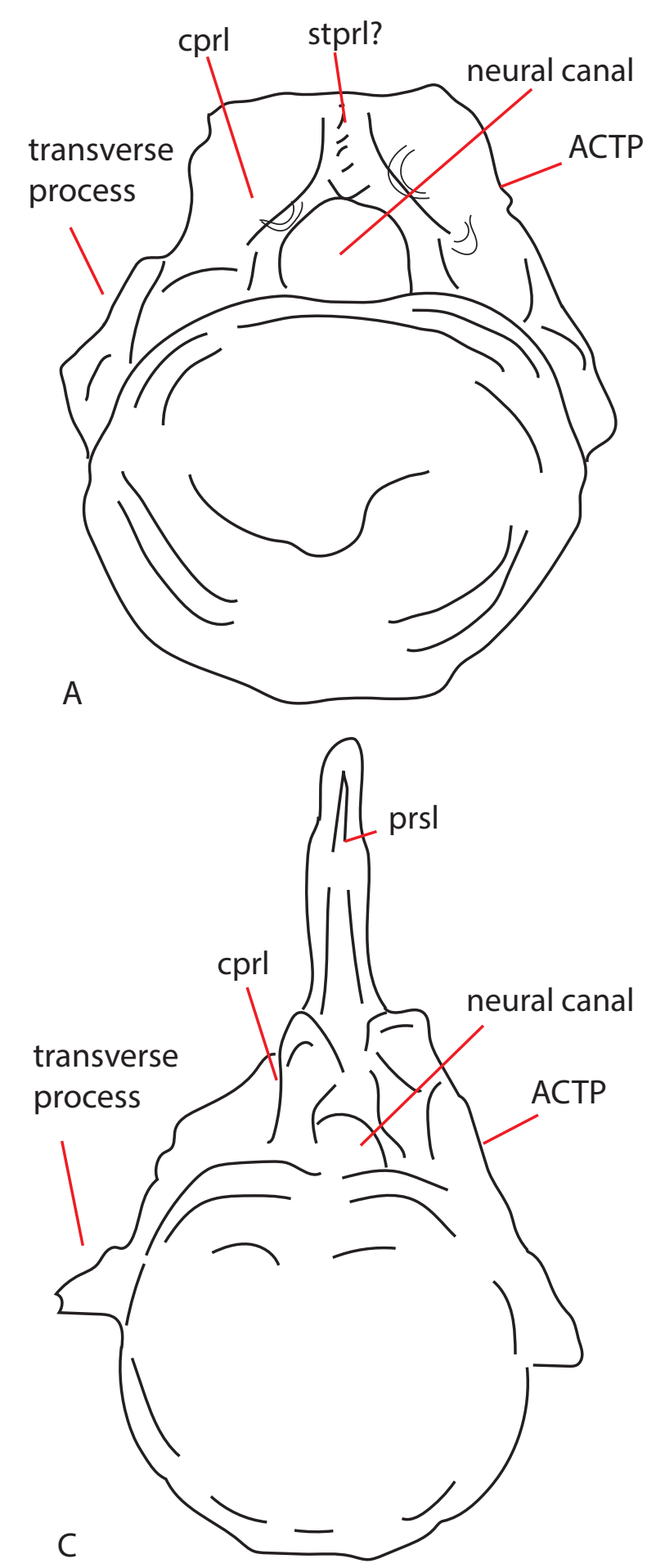

Manuscript to be reviewed

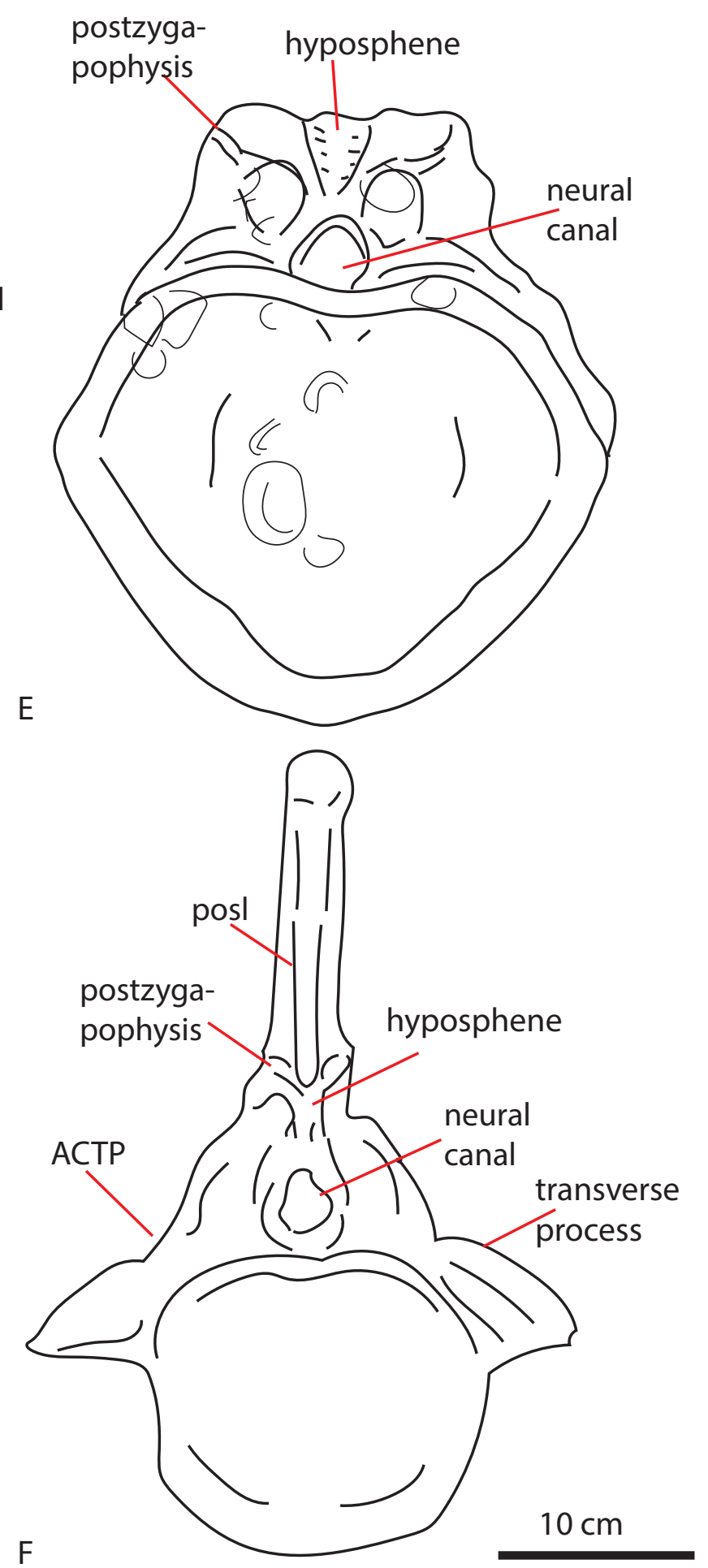




\section{Figure 9 (on next page)}

Figure 9: Comparative schematic drawings of LEICT G. 418.1956.21.0 with middle caudals of other sauropods.

LEICT G. 418.1956.21.0 in lateral view (A) with the Rutland Cetiosaurus (B), Cetiosauriscus (C) and Cetiosaurus oxoniensis (D). Scalebar $10 \mathrm{~cm}$, Cetiosauriscus not to scale. 


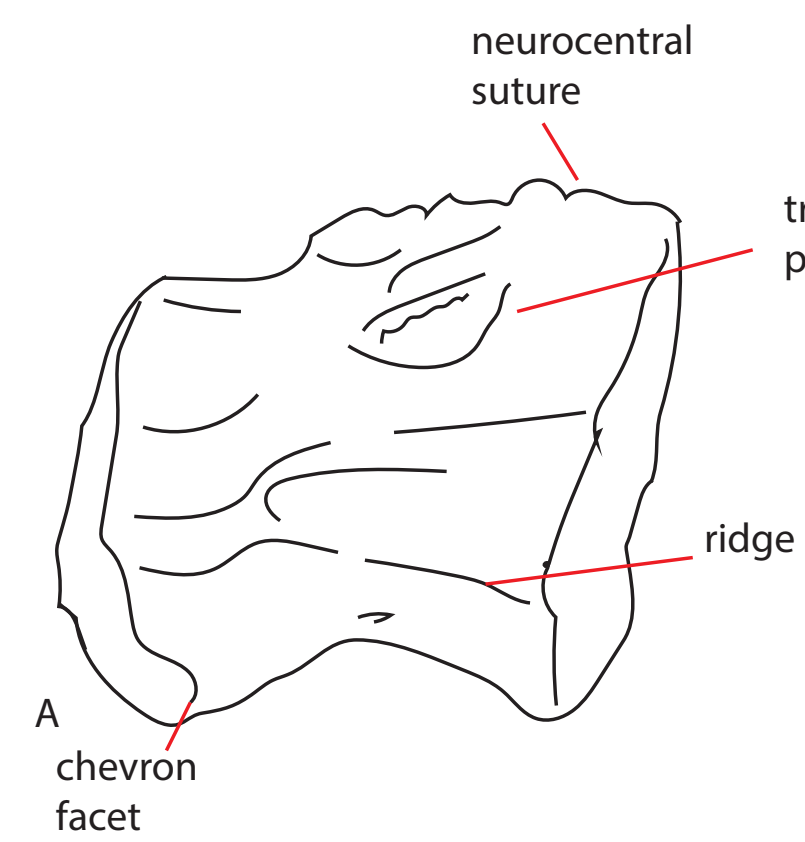

transverse process

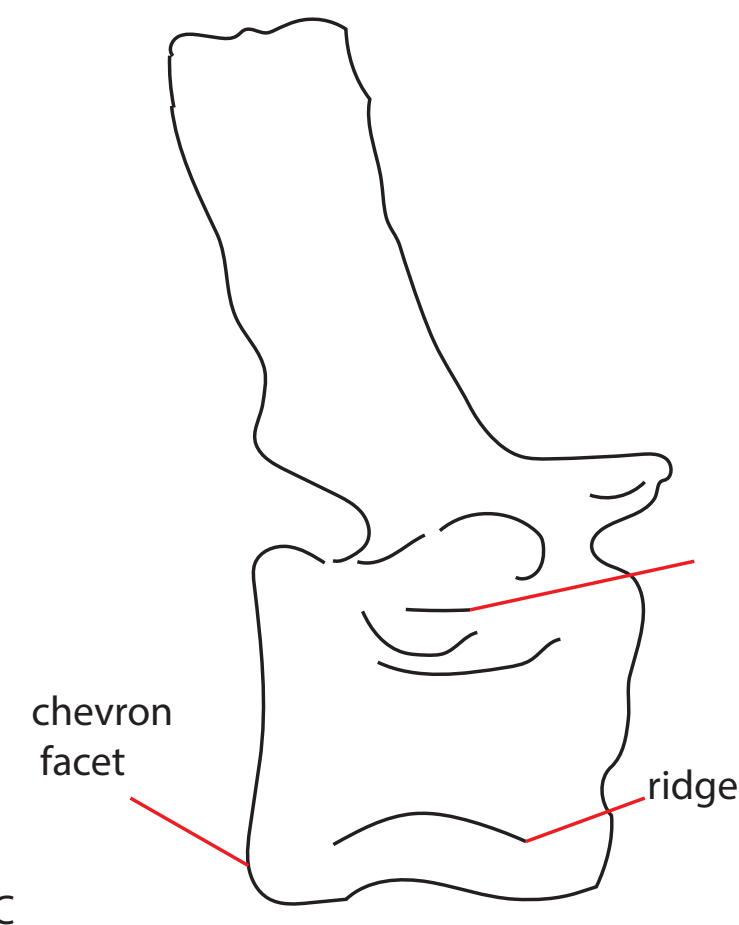

facet

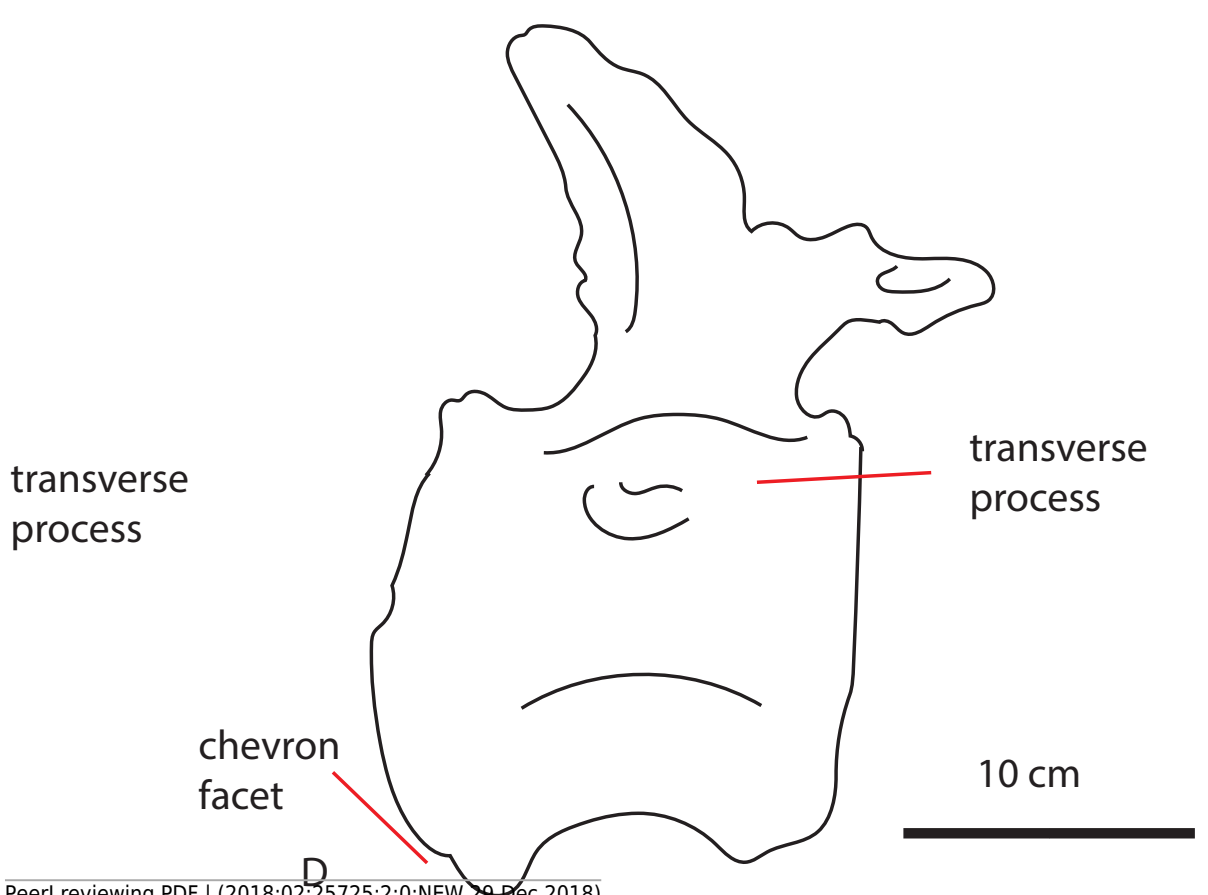




\section{Table 1 (on next page)}

Table 1: Oxford Clay Formation sauropod material. 


\begin{tabular}{|c|c|c|}
\hline Collection reference & material & diagnosis \\
\hline NHMUK R1967 & 10 posterior caudal vertebrae & $\begin{array}{l}\text { Non-neosauropod } \\
\text { eusauropod indet }\end{array}$ \\
\hline NHMUK R1984 & 4 anterior caudal vertebrae & $\begin{array}{l}\text { Non-neosauropod } \\
\text { eusauropod indet }\end{array}$ \\
\hline NHMUK R1985 & Left and right pubis & $\begin{array}{l}\text { Non-neosauropod } \\
\text { eusauropod indet }\end{array}$ \\
\hline NHMUK R1986 & Dorsal centrum (w/o neural arch) & $\begin{array}{l}\text { Non-neosauropod } \\
\text { eusauropod indet }\end{array}$ \\
\hline NHMUK R1987 & Dorsal rib & $\begin{array}{l}\text { Non-neosauropod } \\
\text { eusauropod indet }\end{array}$ \\
\hline NHMUK R1988 & Left and right ischium & $\begin{array}{l}\text { Non-neosauropod } \\
\text { eusauropod indet }\end{array}$ \\
\hline NHMUK R3078 & $\begin{array}{l}\text { posterior dorsal vertebra, a partial } \\
\text { sacrum, a partial caudal axial } \\
\text { column, forelimb and partial } \\
\text { pectoral girdle, hindlimb, and a } \\
\text { partial pelvic girdle }\end{array}$ & Cetiosauriscus stewarti \\
\hline NHMUK R3377 & 3 isolated teeth & ?Turiasauria \\
\hline
\end{tabular}

1 